\title{
PERIODIZATION OF RECENT AND LATE PLEISTOCENE - HOLOCENE GEODYNAMIC AND PALEOCLIMATIC PROCESSES
}

\section{S. V. Rasskazov, K. G. Levi}

Institute of the Earth's Crust SB RAS, Irkutsk, Russia

\begin{abstract}
Based on comparative analyses of spatial and temporal patterns of high- and medium-potassic basaltic eruptions in the Central Mongolia and marine survey records of Sr isotopes, it is revealed that the start of the recent geodynamic stage in the Central Mongolia correlates with the starting point of its global manifestation, which gives an evidence of a close relationship between magmatic occurrences in the region under study and processes of global convergence. The magmatic occurrences are considered as representing the recent geodynamic evolution of the past 90 Ma with milestones of $\sim 66,40-37, \sim 32$ and 17-15 Ma ago. Global changes, except those 32 Ma ago, are shown in marine records of Sr isotopes. The Late Plestocene - Holocene natural and climate setting is reconstructed from radiocarbon datings of various geological and paleobiological objects. Changes of the natural environment and climate of the Northern hemisphere are plotted with account of strong magma eruptions, attacks of asteroids and meteorites, changes of lithological compositions of sedimentary complexes and species compositions of fauna at the given time interval.
\end{abstract}

Key words: Cenozoic, Central Asia, geochronology, cyclicity, volcanism, paleoclimate.

Citation: Rasskazov S.V., Levi K.G. 2014. Periodization of recent and Late Pleistocene - Holocene geodynamic and paleoclimatic processes. Geodynamics \& Tectonophysics 5 (1), 81-100. doi:10.5800/GT-2014-5-1-0118.

\section{ПЕРИОДИЗАЦИЯ СОВРЕМЕННЫХ И ПОЗДНЕПЛЕЙСТОЦЕН- ГОЛОЦЕНОВЫХ ГЕОДИНАМИЧЕСКИХ И ПАЛЕОКЛИМАТИЧЕСКИХ ПРОЦЕССОВ}

\author{
С. В. Рассказов, К. Г. Леви \\ Институт земной коры СО РАН, Иркутск, Россия
}

Аннотация: Приведены результаты исследований, выполненных в лаборатории изотопии и геохронологии и лаборатории кайнозоя ИЗК СО РАН в рамках проектов СО РАН: ИМП № 77 «Изучение закономерностей проявления опасных природных процессов в исторически обозримом прошлом для разработки основ прогноза их поведения на ближайшие десятилетия» (РК 01201282598) и Пр. VIII.69.1. «Факторы, определяющие изменение среды и климата Центральной Азии в кайнозое». На основе сравнительного анализа пространственно-временного распределения высокои умеренно калиевых базальтовых извержений в Центральной Монголии и морских записей изотопов Sr выявлено соответствие начала новейшего геодинамического этапа в Центральной Монголии точке отсчета его глобального выражения, свидетельствующее о тесной связи магматических событий региона с глобальными процессами конвергенции. Эти магматические события рассматриваются как представительные для новейшей геодинамической эволюции литосферы за последние 90 млн лет, в ходе которой определена важнейшая роль рубежей 66, 40-37, 32 и 17- 
15 млн лет назад. Происходившие глобальные изменения, за исключением рубежа 32 млн лет назад, запечатлены в морских записях изотопов Sr. Из анализа радиоуглеродного датирования различных геологических и палеобиологических объектов восстановлена природно-климатическая обстановка позднего плейстоцена и голоцена. Построена кривая, отражающая изменения природной среды и климата Северного полушария с учетом проявления мощных вулканических извержений и астероидно-метеоритных атак, изменение литологического состава осадочных комплексов и видового состава фауны на заданном временном интервале.

Ключевые слова: кайнозой, Центральная Азия, геохронология, изотопы, цикличность, вулканизм, палеоклимат.

\section{1. ВВЕДЕНИЕ}

По проблеме периодизации геодинамических и палеоклиматических процессов проводятся систематические исследования в лаборатории изотопии и геохронологии (рис. 1) и в лаборатории кайнозоя (рис. 2). В первой получены новые результаты при изучении вулканизма новейшего геодинамического этапа, во второй - при изучении различных палеоклиматических процессов позднего плейстоцена и голоцена.

Лаборатория неотектоники и геоморфологии (ныне - лаборатория кайнозоя) ИЗК СО РАН была создана в 1968 г. членом-корреспондентом АН СССР Н.А. Флоренсовым. С 1973 г. ее возглавлял академик Н.А. Логачев, а с 1986 г. - д.г.-м.н. Г.Ф. Уфимцев. Сотрудники лаборатории были активными участниками создания 15-томной монографии «История развития рельефа Сибири и Дальнего Востока», и трое из них Н.А. Флоренсов, Н.А. Логачев и О.М. Адаменко - были удостоены в 1978 г. Государственной премии СССР. Г.Ф. Уфимцев в 1994 г. за труды по географии Азии награжден Русским географическим обществом золотой медалью им. Н.М. Пржевальского. Лабораторией выполнены монографические обобщения по мезокайнозойской тектонике юга Восточной Сибири, морфотектонике и морфолитодинамике Байкальской рифтовой зоны, новейшей тектонике востока России, Внутренней Азии и Евразии в целом. В настоящее время научные исследования коллектива лаборатории проводятся в рамках Междисциплинарного интеграционного проекта фундаментальных исследований СО РАН № 77 «Изучение закономерностей проявления опасных природных процессов в исторически обозримом прошлом для разработки основ прогноза их поведения на ближайшие десятилетия» (РК 01201282598), призванных решать проблемы глобальных и региональных природно-климатических изменений, а также в области геологии и стратиграфии четвертичных отложений рифтовых долин Восточной Сибири. Лаборатория выполняет роль координационного центра в деятельности Ассоциации геоморфологов России, а ее сотрудники проводят совместные научные исследования с коллегами из Улан-Удэ, Новосибирска, Барнаула, Москвы и Санкт-Петербурга, с учеными Италии, Англии, Канады, Китая, ведут преподавательскую дея- тельность в Иркутском госпедуниверситете и Иркутском госуниверситете.

В 1996 г. группа сотрудников лаборатории неотектоники и геоморфологии объединилась с изотопной группой Аналитического центра ИЗК СО РАН в лабораторию изотопии и геохронологии. Изотопную группу возглавлял д.г.-м.Н., профессор геохимии С.Б. Брандт, который в 1970-1980-х гг. организовал измерения возраста пород калий-аргоновым, а затем - рубидий-стронциевым и свинец-свинцовым методами. В 1999 г. лаборатория изотопии и геохронологии явилась базовой для приобретения масс-спектрометра с термической ионизацией фирмы Finnigan MAT (модель 262) - первого прибора Байкальского аналитического центра коллективного пользования за счет инвестиционного кредита Немецкого банка. Лабораторией проводились работы по темам: «Источники магм в эволюции кайнозойских континентальных рифтовых систем» (1996 г.), «Изотопно-геохимическое и геохронологическое обоснование геодинамических моделей» (1997-1998 гг.), «Реконструкция палеогеодинамических обстановок Центрально-Азиатского складчатого пояса (северо-восточный сегмент); изотопно-геохимическое и геохронологическое обоснование геодинамических моделей» (1999-2001 гг.); «Геодинамические и термохронологические модели по изотопно-геохимическим данным» (2002-2003 гг.); «Магматизм, литогенез и сравнительная геохронология мезокайнозоя Внутренней и Восточной Азии» (2004-2006 гг.); «Эволюция седиментогенеза, биоценозов, магматизма и рудообразования в мезозое и кайнозое Внутренней и Восточной Азии» (2007-2009 гг.), «Изучение вулканизма, осадконакопления и экосистем Азии для обоснования рубежей важнейших структурных перестроек позднего мезозоя и кайнозоя» (2010-2012 гг.). В рифтовых системах Байкальской, Восточно-Африканской и РиоГранде выполнялись совместные проекты с учеными США (Массачусетский технологический институт, Смитсоновский институт, Геологическая служба, другие организации), Бельгии (Брюссельский университет, Королевский музей Центральной Африки), Монголии (Исследовательский центр по астрономии и геофизике МАН), Китая (Институт геологии и геофизики КАН). Проводились работы на континентальной окраине Восточной Азии и в Тянь-Шане. Поддерживались 


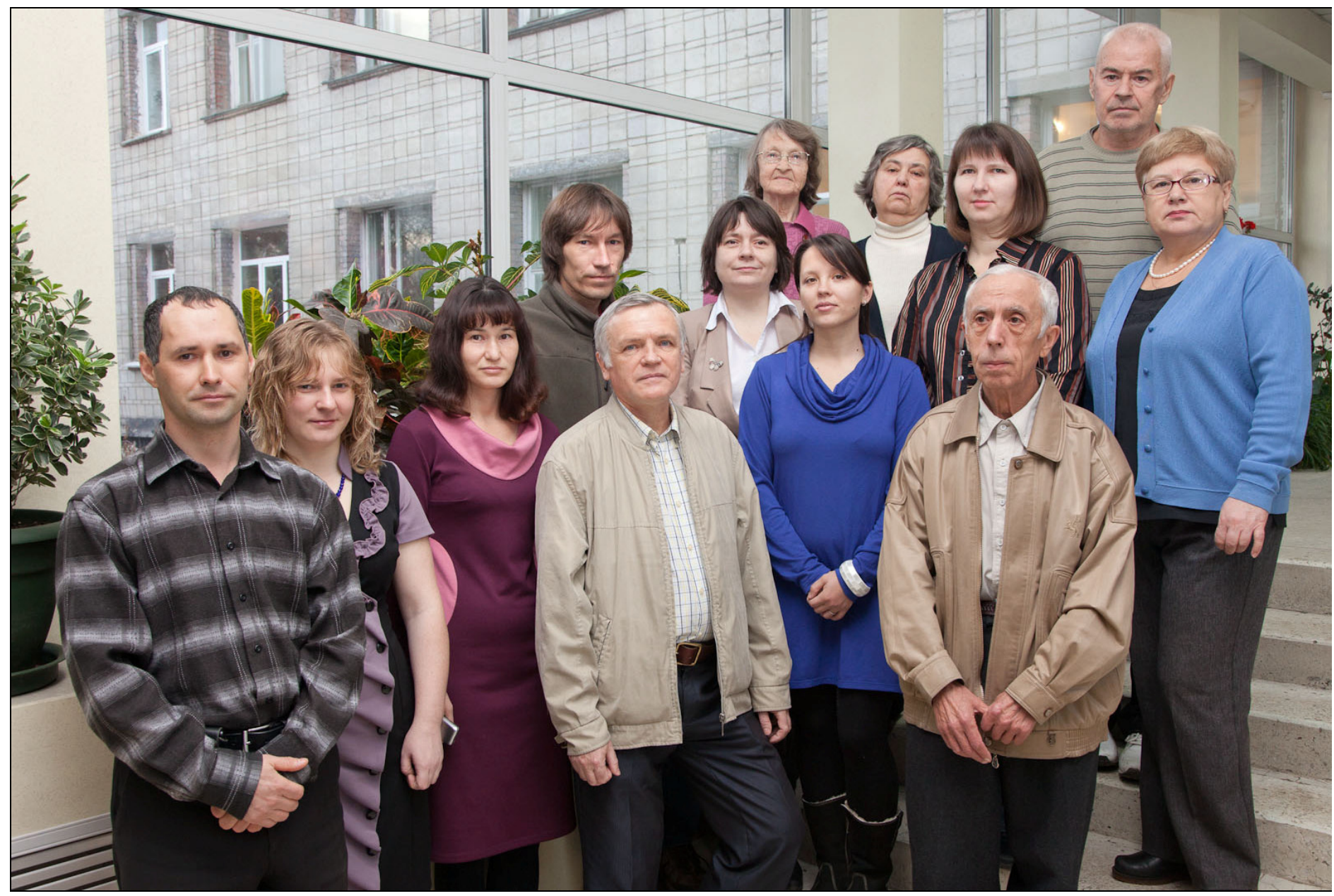

Рис. 1. Лаборатория изотопии и геохронологии.

Первый ряд: к.х.н. А.П. Чебыкин, Е.Н. Воднева, к.г.-м.н. А.М. Ильясова, д.г.-м.н. С.В. Рассказов - зав. лабораторией. Второй ряд: К.В. Ершов, к.г.-м.н. Т.А. Ясныгина, к.г.-м.н. И.С. Чувашова, к.г.-м.н. Н.Н. Фефелов. Третий ряд: М.Е. Маркова, Н.В. Заруднева, к.г.-м.н. Е.В. Саранина, Т.В. Рассказова, С.С. Бранд.

Fig. 1. The staff of the Laboratory of Isotopy and Geochronology.

$1^{\text {st }}$ row - A.P. Chebykin, E.N. Vodneva, A.M. Il'yasova, S.V. Rasskazov (Head of the Laboratory); $2^{\text {nd }}$ row - K.V. Ershov, T.A. Yasnygina, I.S. Chuvashova, N.N. Fefelov; $3^{\text {rd }}$ row - M.E. Markova, N.V. Zarudneva, E.V. Saranina, T.V. Rasskazova, S.S. Brand

контакты с сотрудниками институтов СО и ДВО РАН, а также с геологами «Бурятгеолкома» и других научных и производственных организаций.

\section{2. НОВЕЙШАЯ ГЕОДИНАМИКА И ВУЛКАНИЗМ}

Геоморфологический подход к анализу тектонических движений земной поверхности способствовал выделению в геотектонике особой дисциплины «неотектоника» [Николаев, 1949]. Предметом ее исследований явились новейшие тектонические события, в результате которых были созданы основные черты современного рельефа. Возраст новейших тектонических движений большинством геоморфологов принимался как неоген-четвертичный, но фактически в разных районах мира рельеф формировался с юры, начала кайнозоя, олигоцена, миоцена или квартера. Неоднозначность временного аспекта в понятии «неотектоника» отражена в картах новейшей тектоники Сибири и Дальнего Востока со скользящим возрастом активизации тектонических движений [Логачев и др., 1981; Геология..., 1984; Леви, 1991, 2008].

По аналогии с понятием «новейший этап», используемым в геотектонике, может использоваться понятие «новейший» для обозначения соответствующего этапа в геодинамике как обусловленного действием сил, определивших единую эволюционную последовательность процессов на Земле, которые привели к ее современному состоянию [Рассказов, Чувашова, 2013а, 2013б].

Среди геодинамических процессов особо выделяется вулканизм. Характер эволюции этого процесса в кайнозое Азии оценивался по временному распределе- 


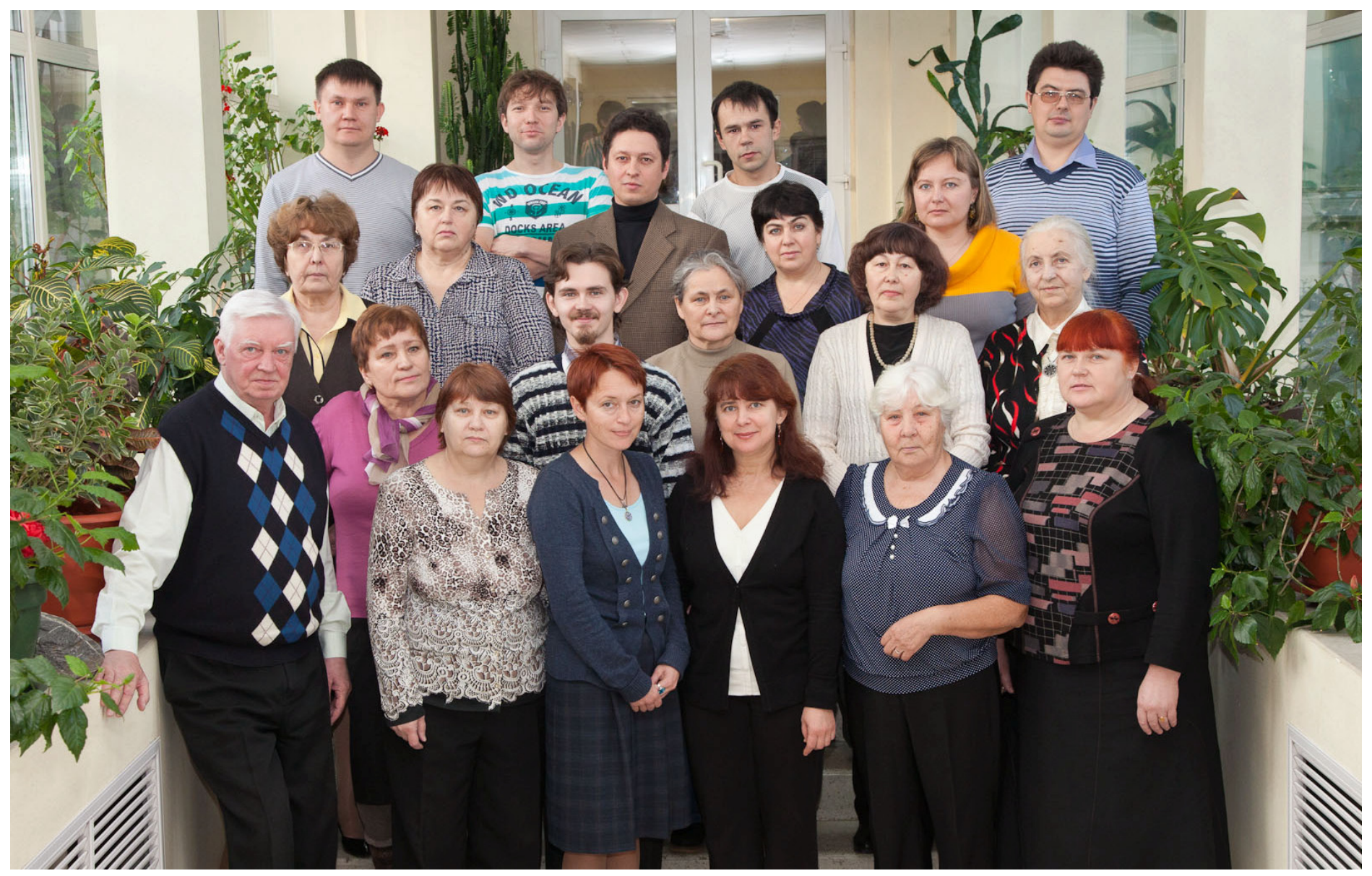

Рис. 2. Лаборатория кайнозоя.

Первый ряд: д.г.-м.н. Леви К.Г. - зав. лабораторией, Н.В. Тирских, к.г.-м.н. Т.М. Сковитина, к.г.-м.н. Е.Г. Вологина, В.А. Мишарина, Е.Г. Полякова. Второй ряд: к.г.-м.н. И.М. Мащук, к.г.-м.н. А.О. Фролов, к.г.-м.н. Н.В. Кулагина, Т.И. Храмцова, к.г.-м.н. Г.П. Черняева. Третий ряд: д.г.-м.н. Г.А. Карнаухова, И.В. Шибанова, к.г.-м.н. А.А. Щетников, О.Н. Шестакова, к.б.н. Е.В. Верхозина. Четвертый ряд: к.г.-м.н. И.А. Филинов, А.В. Сизов, А.С. Козырев, к.г.-м.н. А.М. Клементьев.

Fig. 1. The staff of the Laboratory of the Cenozoic.

$1^{\text {st }}$ row - K.G. Levi (Head of the Laboratory), N.V. Tirskikh, T.M. Skovitina, E.G. Vologina, V.A. Misharina, E.G. Polyakova; $2^{\text {nd }}$ row - I.M. Mashchuk, A.O. Frolov, N.V. Kulagina, T.I. Khramtsova, G.P. Chernyaeva; $3^{\text {rd }}$ row - G.A. Karnaukhova, I.V. Shibanova, A.A. Shchetnikov, O.N. Shestakova, E.V. Verkhozina; $4^{\text {th }}$ row - I.A. Filinov, A.V. Sizov, A.S. Kozyrev, A.M. Klementiev

нию $\mathrm{K}-\mathrm{Ar}$ и ${ }^{40} \mathrm{Ar} /{ }^{39} \mathrm{Ar}$ датировок вулканических пород разных территорий, но без учета возможных изменений характера образования магматических расплавов в мантии и коре [Рассказов и др., 2000; Рассказов, 2002; Ярмолюк и др., 1994, 1995, 2007]. Другой подход к исследованию характера периодичности заключался в изучении источников магм в их общей эволюции с резким отличием от источников, действовавших в ходе предшествующих магматических процессов. В качестве представительной региональной новейшей эволюционной последовательности рассматривалось пространственно-временное распространение извержений высоко- и умереннокалиевых базальтовых магм в Центральной Монголии [Чувашова и др., 2010; Рассказов u дp., 2012]. Независимая информация о глобальной эволюции Земли обеспечивалась изотопным составом
$\mathrm{Sr}$ мирового океана. Поступление $\mathrm{Sr}$ в морскую воду в тот или иной период времени отражало соотношение материала из коровых (обогащённых радиогенным ${ }^{87} \mathrm{Sr}$ ) и мантийных (обеднённых этим изотопом) источников. Региональное и глобальное проявление новейшего геодинамического этапа во временном интервале последних 90 млн лет рассматривается нами в первой части настоящей работы как один из результатов, полученных в лаборатории изотопии и геохронологии ИЗК СО РАН в рамках реализации Программы VIII.69.1.

В фанерозое насчитывается большое число эпизодов массового и малого обновления органического мира, но только семь из них привлекают повышенное внимание: 1) конец ордовика, 2) поздний девон (граница франкского и фаменского веков), 3) граница пер- 


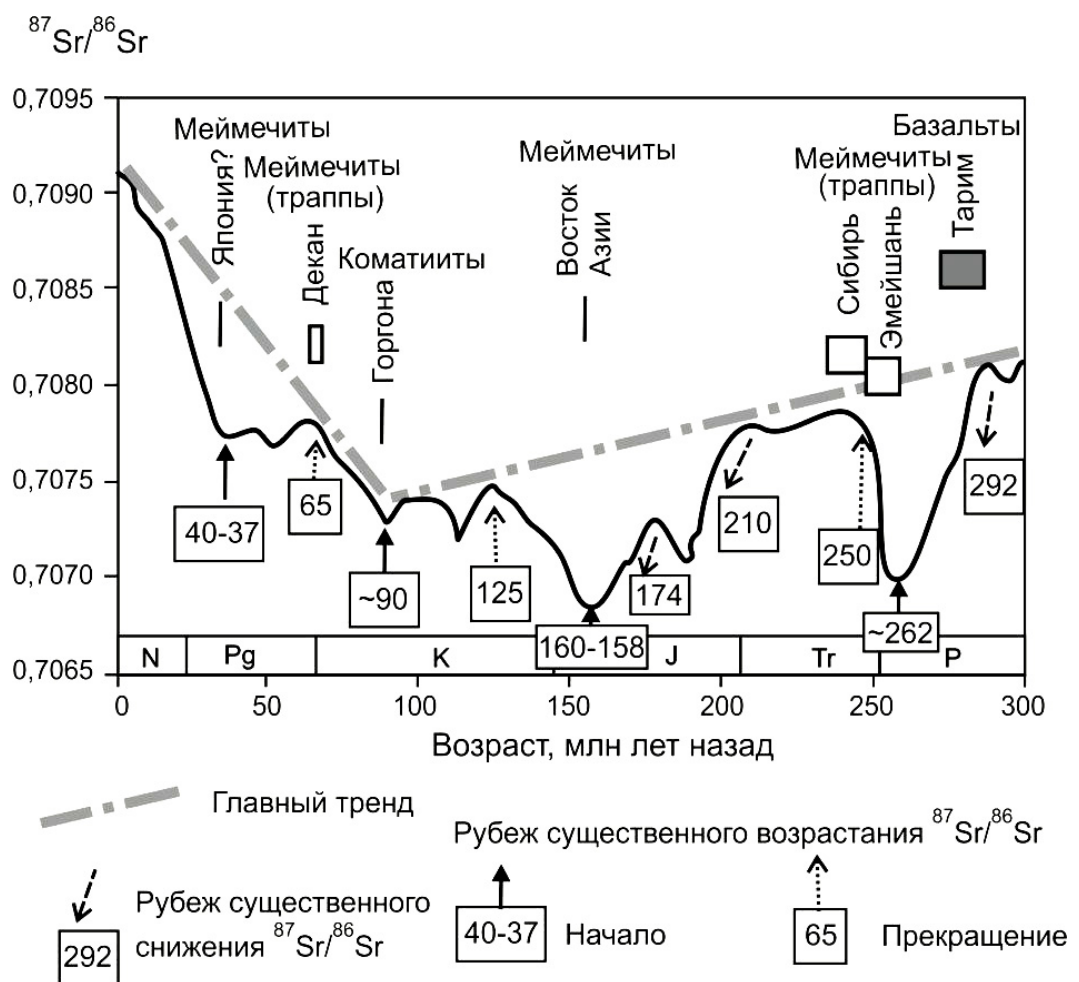

Рис. 3. Изгиб главного тренда вариаций ${ }^{87} \mathrm{Sr} /{ }^{86} \mathrm{Sr}$ в морской воде от раннего-среднего к позднему фанерозою, соответствующий точке отсчета новейшего глобального геодинамического этапа 90 млн лет назад.

Показаны эпизоды извержений ультрамагнезиальных лав (MgO=18-32 мас. \%). Серым прямоугольником нанесен интервал извержений лав крупной Таримской магматической провинции, в которых содержания MgO не превышали 12 мас. \%. Интервал вулканизма в этой провинции соответствует начальному эпизоду пермо-триасового нарушения главного тренда. Использована линия морских записей ${ }^{87} \mathrm{Sr} /{ }^{86} \mathrm{Sr}$ из работы [McArthur et al., 2001]. Обзор использованных данных приведен в работах [Рассказов, Чувашова, 2013а, 2013б].

Fig. 3. The curvature of the main trend of ${ }^{87} \mathrm{Sr} /{ }^{86} \mathrm{Sr}$ variations in sea water from the Early-Middle and Late Phanerozoic, which corresponds to the estimated starting point of the recent global geodynamic stage ( $90 \mathrm{Ma})$.

Period of ultra-magnesia lava eruptions are shown ( $\mathrm{MgO}=18-32 \%$, mass.). The grey triangle shows the lava eruption period of the large Tarimskaya magmatic province, where MgO content did not exceed $12 \%$ (mass.). The volcanism period in the given province corresponds to the initial stage of the Perm-Triassic disruption of the major trend. The marine records of ${ }^{87} \mathrm{Sr} /{ }^{86} \mathrm{Sr}$ published in [McArthur et al., 2001] are used. The analyzed data are reviewed in [Рассказов, Чувашова, 2013а, 2013б].

ми и триаса (Р-T), 4) конец триаса, 5) граница мела и палеогена (K-T), 6) конец эоцена и, наконец, 7) рубеж плейстоцена и голоцена [Хаин, 2003; Ward, 2006].

Три последних эпизода относятся к новейшему геодинамическому этапу. Эпизод обновления органического мира рубежа плейстоцена-голоцена, на который обратил внимание В.Е. Хаин, важен для понимания современной геодинамической и климатической обстановки на Земле. В качестве причин «Великих вымираний» растений и животных во главу угла выносятся несколько - активизация вулканизма с массовыми излияниями лав и выбросами ядовитых газов и вулканического пепла в атмосферу, мощные импактные события от падения на земную поверхность астероидов и кометных ядер и экологические причины, связанные с изменением кормовых цепей в животном мире. Наилучшим образом может быть охарактеризована климатическая периодизация позднего плейстоцена и голоцена.

\section{1. ОПРЕДЕЛЕНИЕ РУБЕЖЕЙ НОВЕЙШЕГО ГЕОДИНАМИЧЕСКОГО ЭТАПА}

На морской Sr-изотопной шкале [McArthur et al., 2001] выделен главный тренд вариаций ${ }^{87} \mathrm{Sr} /{ }^{86} \mathrm{Sr}$ с изгибом на рубеже 90 млн лет, принятый в качестве поворотного пункта в переходе от геодинамического этапа раннего и среднего фанерозоя к этапу позднего фанерозоя. На ранне-среднефанерозойском этапе главному тренду соответствуют максимальные значения ${ }^{87} \mathrm{Sr} /{ }^{86} \mathrm{Sr}$ во временных интервалах 305-285, 245-205, а также 125 и 100 млн лет назад, на позднефанерозойском - максимальные значения ${ }^{87} \mathrm{Sr} /{ }^{86} \mathrm{Sr}$ в интервалах 85-65 и $<15$ млн лет назад. На обоих этапах фанерозоя наклоны обозначенных временных отрезков линий морских записей ${ }^{87} \mathrm{Sr} /{ }^{86} \mathrm{Sr}$ согласованы с наклоном линии главного тренда (рис. 3).

По данным из работы [McArthur et al., 2001], максимальные отношения ${ }^{87} \mathrm{Sr} /{ }^{86} \mathrm{Sr}$ в морской воде составля- 
ли 410 млн лет назад величину 0.7088, а в интервале 500-490 млн лет назад достигали значений 0.70915, т.е. находились на уровне, близком к современному ${ }^{87} \mathrm{Sr} /{ }^{86} \mathrm{Sr}$. В свете интерпретации изотопного состава $\mathrm{Sr}$ с выделением главного тренда основную стабилизирующую роль в эволюции Земли играло осаждение в составе карбонатов мирового океана континентального стронция, а относительные отклонения от него с понижением ${ }^{87} \mathrm{Sr} /{ }^{86} \mathrm{Sr}$ отражали наложенный процесс контаминации морской воды мантийным стронцием. Отношение ${ }^{87} \mathrm{Sr} /{ }^{86} \mathrm{Sr}$ главного тренда снизилось в период от 500 до 100 млн лет назад от 0.70915 до 0.70740. Затем это отношение главного тренда с 85 млн лет назад до настоящего времени возросло от 0.7074 до 0.7092 .

Эпизод около 90 млн лет назад примечателен извержениями коматиитов о-ва Горгона. Подобные магмы из источников обедненного типа были характерны для ранних стадий эволюции Земли, и их проявление на о. Горгона - уникальное событие для временного интервала последнего миллиарда лет [Arndt et al., 2008]. Ультрамагнезиальные магмы из источников обогащенного типа - меймечиты - имели более широкое распространение в истории Земли.

Имеется ряд независимых фактов, которые можно интерпретировать в пользу различий между геодинамическими обстановками раннего-среднего и позднего фанерозоя. Переход между этими обстановками сопровождался глобальной перестройкой кинематики литосферных плит и глубинного режима геодинамо.

Позднефанерозойские рубежи морских записей ${ }^{87} \mathrm{Sr} /{ }^{86} \mathrm{Sr}(\sim 90,65,40-37$ и 17-15 млн лет назад) отчетливо обозначены в магматической активности и тектонических перестройках разных регионов. Так, магматизм окраинно-континентального Восточно-СихотэАлинского пояса начинался около 90 млн лет назад и завершился около 65 млн лет назад. В Юго-Западной Японии этим же временным диапазоном ограничивалась эксгумационная активность пояса Санбагава, сопровождавшаяся магматизмом пояса Риоке [Rasskazov, Taniguchi, 2006].

Незначительные изменения ${ }^{87} \mathrm{Sr} /{ }^{86} \mathrm{Sr}$ в интервале 66-37 млн лет назад соответствовали интервалу ИндоАзиатской коллизии и среднеэоценовой структурной перестройке. Главный тренд, нарушенный Индо-Азиатской коллизией и другими процессами, восстанавливался в интервале 37-15 млн лет назад, подобно тому как восстанавливался главный ранне-среднефанерозойский тренд. В раннем и среднем фанерозое нарушение главного тренда осуществлялось подпиткой мантийным материалом с нисходящими значениями ${ }^{87} \mathrm{Sr} /{ }^{86} \mathrm{Sr}$ морских записей, а в дальнейшем роль этой подпитки нивелировалась. В позднем фанерозое фаза подпитки с нисходящими значениями ${ }^{87} \mathrm{Sr} /{ }^{86} \mathrm{Sr}$ отсутствовала, а осуществлялось только увеличение этих отношений.

Изгибы Sr-изотопной кривой около 65 и 37 млн лет назад приблизительно совпадают с крупными импактными событиями. Первое сопровождалось великим вымиранием биоты, второе - малым вымиранием [Ward, 2006]. Первое событие широко известно благодаря глобальному распространению иридиевой аномалии в осадочных отложениях на К-Т-границе, связанной с образованием импактного кратера Чиксулуб на п-ове Юкотан в Мексике [Rasskazov et al., 2010; and references therein]. Второе событие менее известно. С ним связывается образование импактных кратеров: Попигайского в Сибири ( $\varnothing \approx 100$ км), залива Чезапик, атлантическая окраина США ( $\varnothing \approx 90$ км), Уанапитей, Канада ( $\varnothing \approx 7.5$ км) Логойск, Белоруссия ( $\varnothing \approx 17$ км) и Мистастин, Канада ( $\varnothing \approx 28$ км). Датировки импактных событий находятся в интервале 35.5-35.7 млн лет [Koeberl et al., 1996; Glass, 2002; Sanford, 2003].

Характер импульсов раннего-среднего фанерозоя объясняется повышением в океанской воде роли изотопно-обеднённого мантийного материала. Мантийный материал мог поступать благодаря увеличению скорости спрединга океанского дна, размыву океанических плато и других сооружений и т.Д. Сейчас невозможно составить полное представление о вкладе в изотопный баланс Sr эндогенных и экзогенных процессов. Важно подчеркнуть наличие этого вклада и эпизодический переход в состояние, соответствовавшее главному тренду. Около 90 млн лет назад динамика мантийных и коровых процессов изменилась. Теперь поступление изотопно-обеднённого мантийного материала уже не имело самостоятельного значения, а получило существенное распространение растворение в океанской воде корового материала, выраженное в последовательном возрастании ${ }^{87} \mathrm{Sr} /{ }^{86} \mathrm{Sr}$. Это нарастание было прервано Индо-Азиатской коллизией и другими процессами. В дальнейшем в океанской воде растворялся вновь преимущественно коровый материал с высоким ${ }^{87} \mathrm{Sr} /{ }^{86} \mathrm{Sr}$.

\section{2. ВЫРАЖЕНИЕ ГЕОДИНАМИЧЕСКОЙ ПЕРИОДИЧНОСТИ В ПРОСТРАНСТВЕННО-ВРЕМЕННОМ РАСПРЕДЕЛЕНИИ ИЗВЕРЖЕНИЙ ВЫСОКО- И УМЕРЕННОКАЛИЕВЫХ БАЗАЛЬТОВЫХ ЛАВ В ЦЕНТРАЛЬНОЙ МОНГОЛИИ}

\subsection{1. Смена магматизма около 90 млн лет назад}

В разных районах Азии находятся мантийные и коровые магматические породы фанерозоя. Преобладают продукты плавления континентальной коры. Террейны, сложенные породами корового генезиса, разделены шовными зонами сомкнувшихся берегов УралоМонгольского, Туркестанского, Солонкерского палеоокеанов и Монголо-Охотского залива Тихого океана. На протяжении большей части фанерозоя роль коровых источников в геологических структурах Азии была существенной и резко снижалась около 90 млн лет назад. Начиная с этого времени мантийные выплавки стали преобладать, а коровые проявлялись эпизодически [Rasskazov, Taniguchi, 2006; Рассказов и др., 2012; 


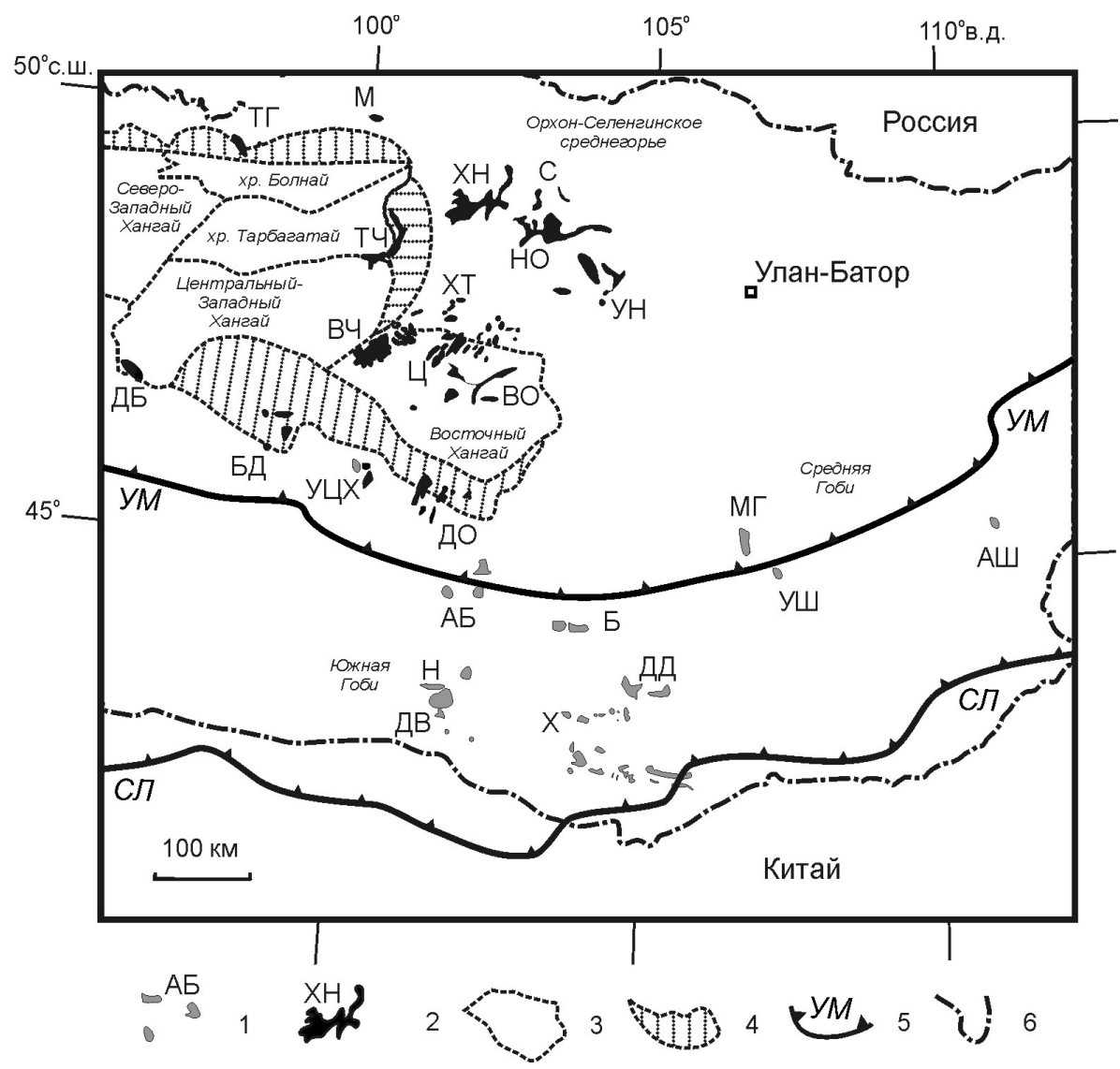

Рис. 4. Пространственное распределение вулканических полей позднего мела и кайнозоя в Центральной Монголии.

1-2 - вулканические поля двух возрастных интервалов: 1 - 91-32 млн лет Гобийской системы (УЦХ - Улан-Цаб-Худукское, Б - Булганское, ДД - Даланзадгадское, МГ - Мандалгобийское, УШ - Ундэршилское, АШ - Алтан-Ширэ, АБ - Арц-Богдское, Н - Ноёнское, Х Хурмэнское, ДВ - Дурвэлджин), 2 - <32 млн лет Хангайской системы (ДО - Долино-Озерское, БД - Байдарикское, ДБ - Дзабханское, М - Мурэнское, Ц - Цэцэрлэгское, ХТ - Хойт-Тамирское, ВО - Верхнеорхонское, ВЧ - Верхнечулутынское, ТЧ - Тарят-Чулутынское, УН - Угей-Нурское, НО - Нижнеорхонское, ХН - Хануйское, С - Селенгинское, ТГ - Тэсийн-Гольское); 3 - орогенная провинция; 4 - пограничная провинция орогена [Корина, 1982]; 5 - шов закрывшегося палеоокеана (УМ - Урало-Монгольского, СЛ - Солонкерского, шов монголо-охотской части Палеопацифика, протягивающийся с востока до Хангайского орогена, на рис. не показан); 6 - государственная граница Монголии.

Fig. 4. The spatial pattern of the Late Cretaceous and Cenozoic volcanic fields of the Central Mongolia.

1-2 - volcanic fields if two ages: 1 - 91-32 Ма, Gobi system (УЦХ - Ulan-Tsab-Khuduk, Б - Bulgan, ДД - Dalanzasgad, МГ - Mandalgobi, УШ - Undershil, АШ - Altan-Shira, АБ - Arts-Bogd, H - Noyon, X - Khurman, ДВ - Durvalgin), 2 - <32 Ma, Khangay system (ДО - DolinaOzerskoe, БД - Baidarik, ДБ - Dzabkhan, M - Muren, Ц - Tsetserlag, XТ - Khoit-Tamir, ВO - Verkhneorkhon, ВЧ - Verkhnechulutyn, ТЧ Taryat-Chulutyn, УH - Ugei-Nur, HO - Nizhneorkhon, XH - Khanuy, C - Selenga, ТГ - Teisiyn-Gol); 3 - orogenic province; 4 - marginal province of the orogen [Корина, 1982]; 5 - suture of the closed ocean (УМ - Ulal-Mongolian, СЛ - Solonkersky; the figure does not include the suture of the Mongol-Okhotsk part of the Paleo Pacific from the east towards the Khangai orogen); 6 - the state border of Mongolia.

Рассказов, Чувашова, 2012]. По единообразному мантийному характеру источников магматизм последних $\sim 90$ млн лет на территории Азии может рассматриваться в качестве процесса новейшего геодинамического этапа и, таким образом, отличаться от предшествующего ранне-среднефанерозойского магматизма с мантийно-коровым характером источников.

\subsection{2. Цикличность высоко- и умереннокалиевого мантийного магматизма в последние 90 млн лет}

Вулканизм последних 90 млн лет Центральной Азии развивался неравномерно в пространстве и вре- мени. Вулканические извержения мигрировали на десятки, а иногда первые сотни километров. В Центральной Монголии различаются Гобийская и Хангайская системы вулканических полей с возрастными интервалами, соответственно, 91-32 и менее 32 млн лет (рис. 4). Особенности пространственно-временной эволюции вулканизма Центральной Монголии отражены в вариациях концентраций калия и $\mathrm{K} / \mathrm{Na}$ отношений [Чувашова и др., 2010; Рассказов и др., 2012].

Рубеж около 90 млн лет назад обозначен сменой высококалиевых лав умереннокалиевыми в р-не хр. Арц-Богд Южной Гоби. Высокое содержание калия $(\mathrm{K}=3.35$ мас. \%) и высокое калинатровое отношение 


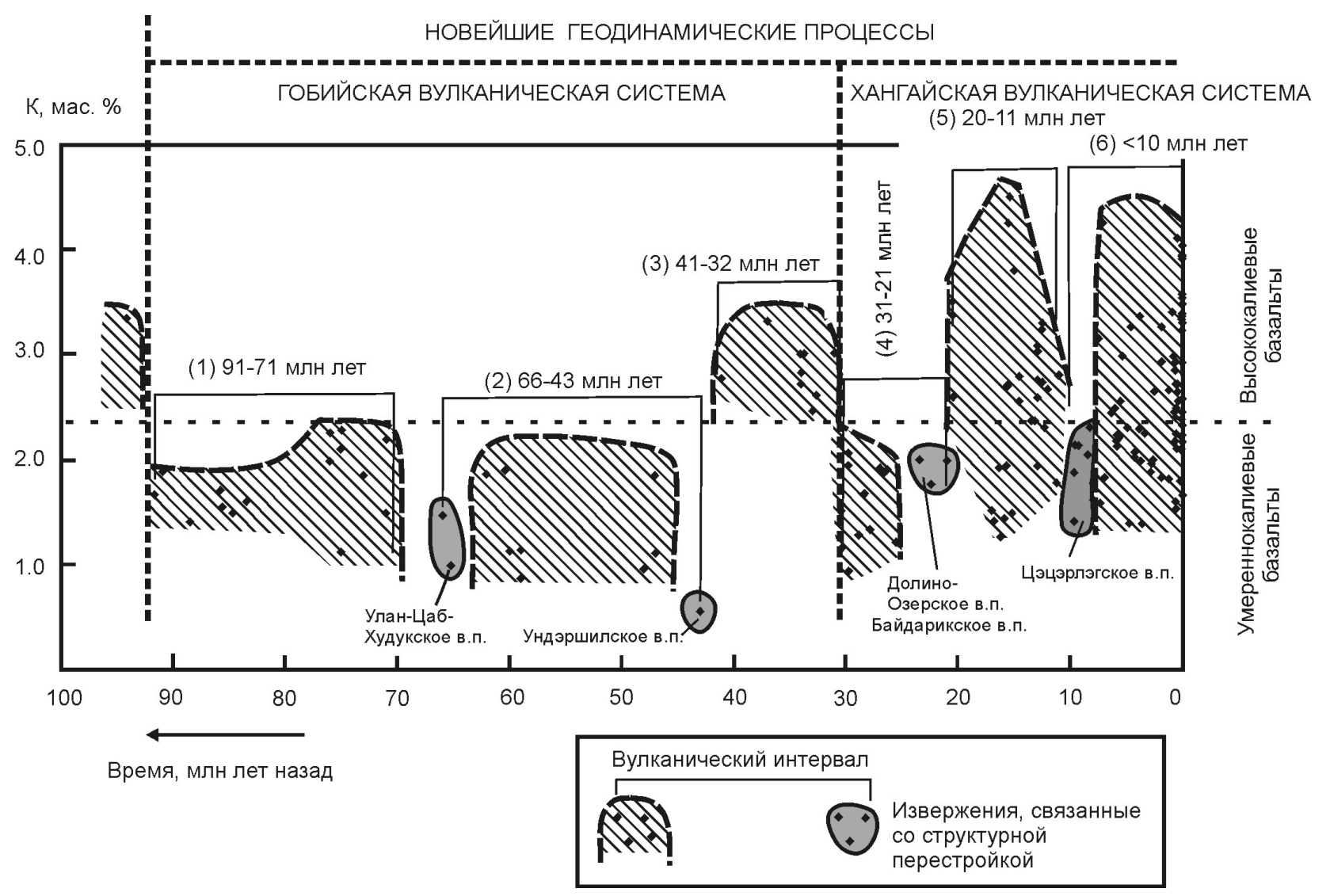

Рис. 5. Временные вариации калия в вулканических породах позднего мела и кайнозоя Центральной Монголии.

Таблица датировок [Рассказов и др., 2012; Свидетельство..., 2013]. Нижнее ограничение новейших геодинамических процессов обозначено датировкой 94.4 \pm 2.2 млн лет латита с содержанием K=3.35 мас. \% из района хр. Арц-Богд [Enkhtuvshin, 1995].

Fig. 5. Variation of potassium with time in the Late Cretaceous and Cenozoic volcanic rocks of the Central Mongolia.

The datings are published in [Рассказов и др., 2012; Свидетельство..., 2013]. The lower limit of the recent geodynamic processes is $94.4 \pm 2.2$ Ma in datings of latite (K=3.35 \%, mass.) from the area of the Arts-Bogd ridge, according to [Enkhtuvshin, 1995].

$\left(\mathrm{K}_{2} \mathrm{O} / \mathrm{Na}_{2} \mathrm{O}=1.2\right)$ определено в латите, излившемся около 94 млн лет назад. Для латитов и ассоциирующихся с ними шошонитов и трахибазальтов характерны низкие содержания MgO (1.4-3.1 мас. \%), высокие $\mathrm{Ba} / \mathrm{Sr}$ (1.2-1.4), повышенные начальные изотопные отношения стронция (до 0.70533) и низкие - неодима (до 0.512250) [Enkhtuvshin, 1995]. Такие характеристики отражают происхождение расплавов из коровых источников. В позднемеловых лавах Южной Гоби, извергнутых во временном интервале 91-71 млн лет назад, измерены умеренные концентрации калия (K = =1.4-1.7 мас. \%) при повышенных содержаниях $\mathrm{MgO}$ (до 8.5 мас. \%), сравнительно низкие $\mathrm{Ba} / \mathrm{Sr}(0.52-0.73)$, широкие диапазоны начальных отношений изотопов $\mathrm{Sr}$ и $\mathrm{Nd}$ - от обогащенных (относительно примитивный мантии) до обедненных [Ярмолюк и др., 2007]. Эти характеристики сопоставляются с характеристиками кайнозойских лав, производных преимущественно мантийных источников [Рассказов и др., 2012].

По вариациям концентраций калия в позднемеловых и кайнозойских лавах различаются шесть времен- ных интервалов вулканизма: 1) позднемеловой (91-71 млн лет назад), 2) палеоцен-среднеэоценовый (66-43 млн лет назад), 3) среднеэоценовый-раннеолигоценовый (41-31 млн лет назад), 4) олигоцен-раннемиоценовый (32-21 млн лет назад), 5) миоценовый (20-11 млн лет назад) и 6) позднемиоценовый-четвертичный ( $<10$ млн лет назад). Первые три интервала рассматриваются как события Гобийской вулканической системы, последние три - Хангайской (рис. 5).

Рассредоточенный базальтовый магматизм палеоцена - среднего эоцена, умереннокалиевый по составу, был отделен от предшествовавшего и более позднего магматических интервалов эпизодами извержений базальтов 66-65 и 43 млн лет назад с относительно низкой концентрацией калия (0.5-1.5 мас. \%). Высококалиевые лавы начали извергаться с 41 млн лет назад. Группы высоко- и умереннокалиевых базальтов были частично разделены во времени.

Периодичность проявлений высоко- и умереннокалиевых лав с течением времени менялась. За фазой извержений высококалиевых лав хр. Арц-Богд 19.6 


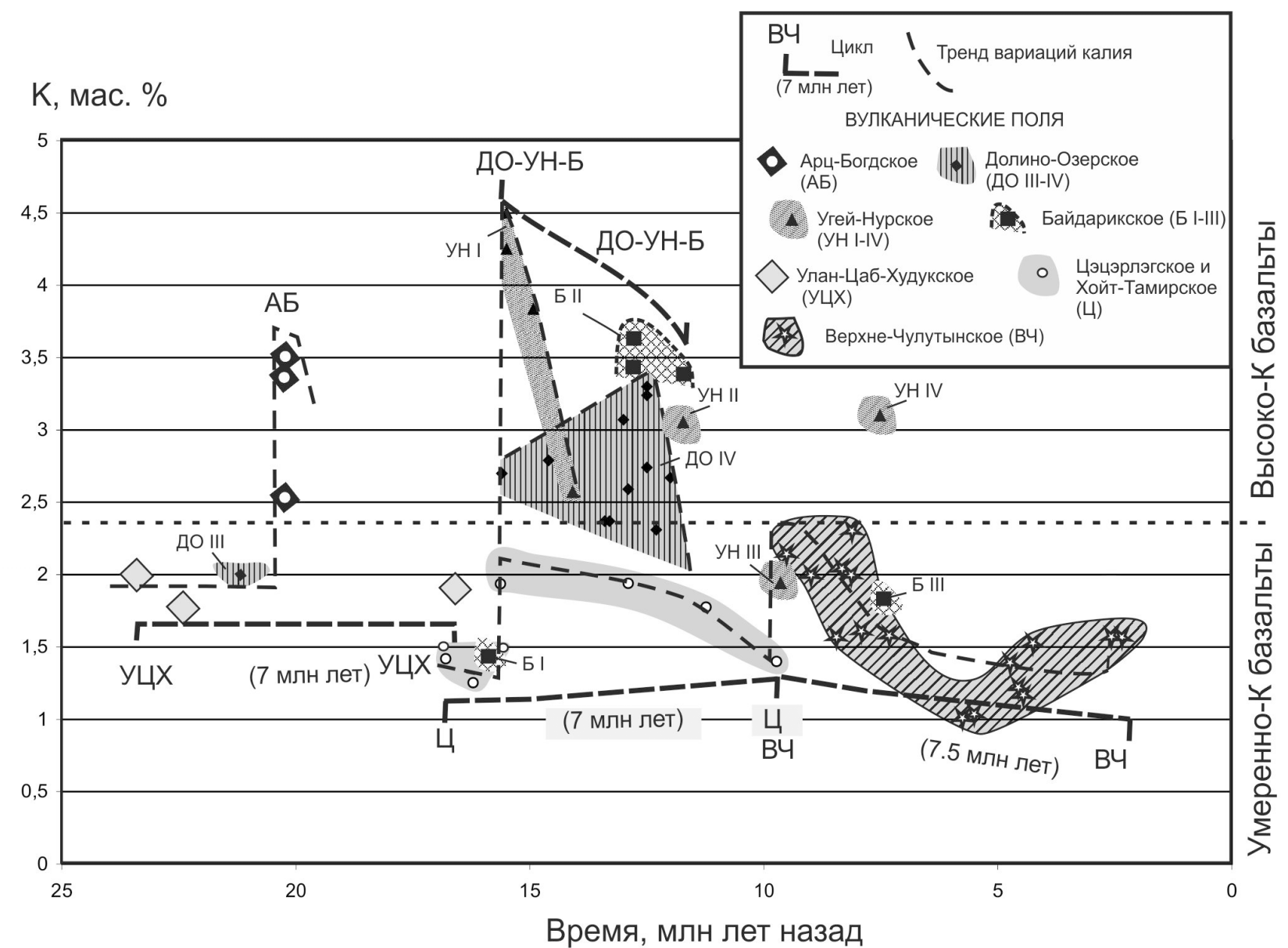

Рис. 6. Соотношения извержений высоко- и умереннокалиевых лав Центральной Монголии во временном интервале 23.42.1 млн лет назад.

Таблица датировок [Рассказов и др., 2012; Свидетельство..., 2013]. По датировкам пород разных вулканических полей обозначены циклы высоко- и умереннокалиевого магматизма с квазипериодичностью, соответственно, 4.5 и 7.0 млн лет.

Fig. 6. Ratios between eruptions of high- and medium-potassic basaltic eruptions in the Central Mongolia in the time interval of 23.4-2.1 Ma ago.

The datings are published in [Рассказов и др., 2012; Свидетельство..., 2013]. Based on datings of rocks from various volcanic fields, cycles of high- and medium-potassic magmatism are shown in the quasi-periodical patterns of 4.5 and $7.0 \mathrm{Ma}$, respectively.

млн лет назад через 4 млн лет следовали извержения лав 15.6 млн лет назад с концентрацией калия $\sim 2.7$ мас. \% на Долино-Озерском поле. Извержения на нем продолжались до 12.2 млн лет назад с относительным повышением калия до 3.3 мас. \%, сопровождаясь извержениями лав Байдарикского поля интервала 13-11 млн лет назад с более высокой концентрацией калия (3.4-3.6 мас. \%). На Байдарикском поле эта вулканическая фаза предварялась и сменялась фазами извержений умереннокалиевых лав, соответственно 15.6 и 7.0 млн лет назад, а на Угей-Нурском поле, наоборот, фаза извержений умереннокалиевых лав 9.6 млн лет назад предварялась и сменялась фазами извержений высококалиевых лав, соответственно, 15.5-14.2 и 7.4 млн лет назад. Подобным образом концентрации калия варьировались в противофазе в лавах хр. Восточный Хангай и Орхон-Селенгинского среднегорья. Извержениями умереннокалиевых базальтов на Улан-Цаб-Худукском, Цэцэрлэгском и Верхнечулутынском вулканических полях обозначились более длительные магматические квазипериоды порядка 7 млн лет (рис. 6).

Умереннокалиевый вулканизм Цэцэрлэгского поля продолжался с 17.0 до 9.7 млн лет назад при относительном повышении концентраций калия, согласованном во времени с началом высококалиевого вулканизма Долино-Озерского и Угей-Нурского полей 15.615.5 млн лет назад. Это вызвано эффектом наложения процессов высококалиевого магматизма на ход эволюции умереннокалиевых расплавов, что свидетельствует о частичной согласованности эволюции мантийных процессов с быстрым эпизодическим воспроизводст- 


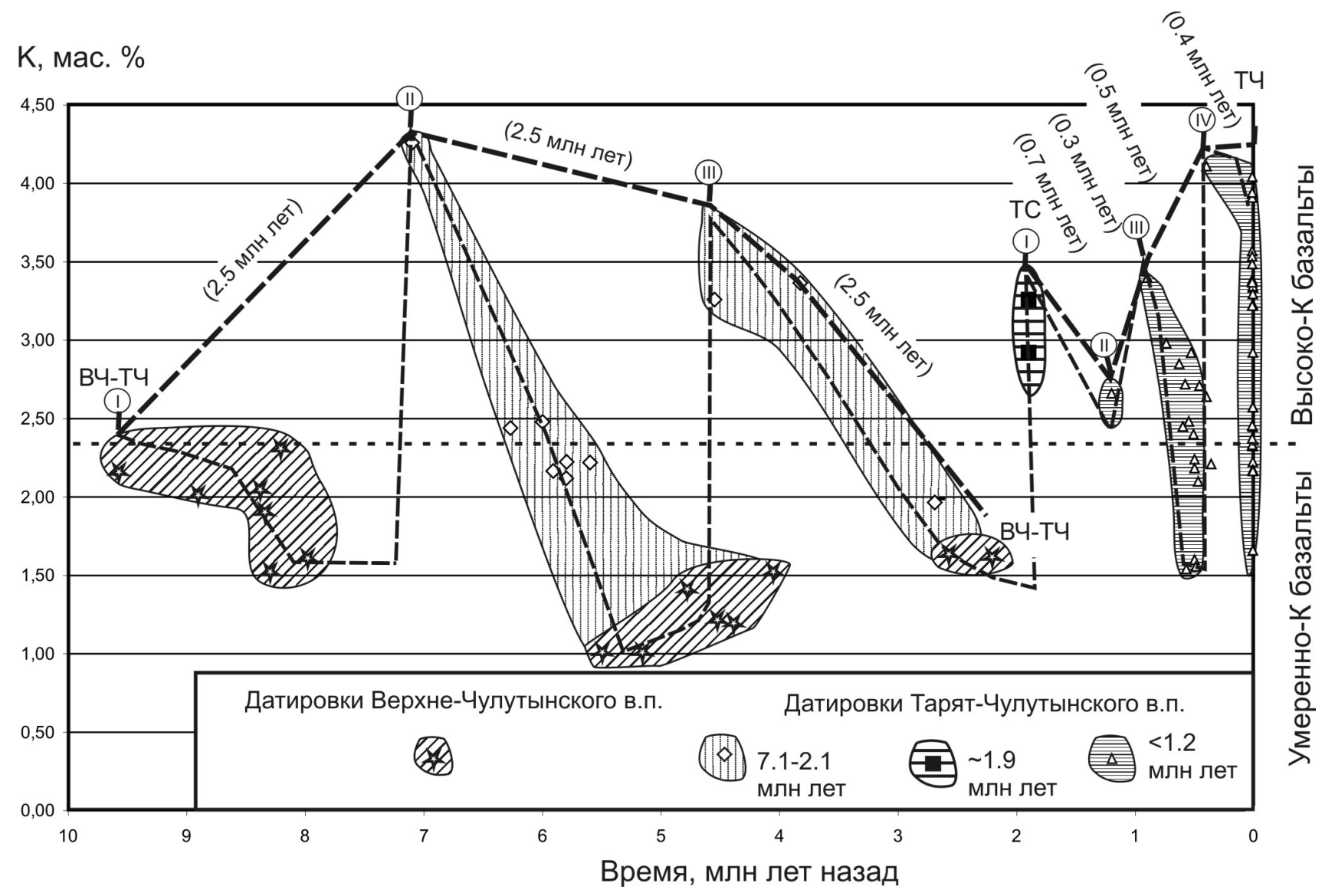

Рис. 7. Переход от извержений Верхнечулутынского и Тарят-Чулутынского вулканических полей в интервале 9.6-2.1 млн лет назад с согласованными цикличными вариациями калия в лавах (циклы I-III с квазипериодичностью 2.5 млн лет) к извержениям на Тарят-Чулутынском поле (циклы I-IV с квазипериодичностью 0.3-0.7 млн лет).

Таблица датировок [Рассказов и др., 2012; Свидетельство..., 2013].

Fig. 7. Transition from eruptions of the Verkhnechulutyn and Taryat-Chulutyn volcanic fields in the interval of 9.6-2.1 Ma ago with cyclic variations of potassium in lavas (cycles I, II and III with quasi-periodicity of $2.5 \mathrm{Ma}$ ) which are correlated with eruptions at the Taryat-Chulutyn volcanic field (cycles I, II, III and IV with quasi-periodicity of 0.3-0.7 Ma).

The datings are published in [Рассказов и др., 2012; Свидетельство..., 2013].

вом высококалиевых магм и замедленным, продолжительным - умереннокалиевых.

В интервале 10-2 млн лет назад временные вариации калия в базальтах Верхнечулутынского и ТарятЧулутынского полей были согласованы между собой с квазипериодичностью 2.5 млн лет. На Тарят-Чулутынском поле эта квазипериодичность выражена в фазах извержений высококалиевых лав 7.1 и 4.6-3.8 млн лет назад. На Верхнечулутынском поле высококалиевые лавы неизвестны. Лавы умереннокалиевого состава, излившиеся в интервале 9.6-8.0 млн лет назад, составляли вулканический цикл, предшествовавший извержениям Тарят-Чулутынского поля, а лавы интервалов 5.5-4.0 и 2.6-2.1 млн лет назад обозначали финальные фазы извержений с минимальными концентрациями калия двух других циклов. Квазипериодичность 2.5 млн лет характерна для вулканической деятельности в Байкальской рифтовой зоне и на конти- нентальной окраине Восточной Азии [Рассказов и др., 2000; Рассказов, 2002; Rasskazov, Taniguchi, 2006]. В последние 2 млн лет извержения на Верхнечулутынском поле не возобновлялись, а фазы высококалиевых извержений Тарят-Чулутынского поля выстраивались в четыре цикла с квазипериодичностью 0.3-0.7 млн лет. Два последних включали, кроме высококалиевых, лавы умереннокалиевого состава (рис. 7).

\section{3. ПОЗДНИЙ ПЛЕЙСТОЦЕН И ГОЛОЦЕН}

Достоверных данных об извержениях вулканов в интервале последних 400 тыс. лет нет. Самые древние датированные извержения вулканов Атитлан (87-84 тыс. лет назад) и Тоба (77-69 тыс. лет назад) вызвали существенные похолодания за счет выбросов пепла в атмосферу. Однако в похолодания внесли свой вклад и 
$\ln \mathrm{E}$

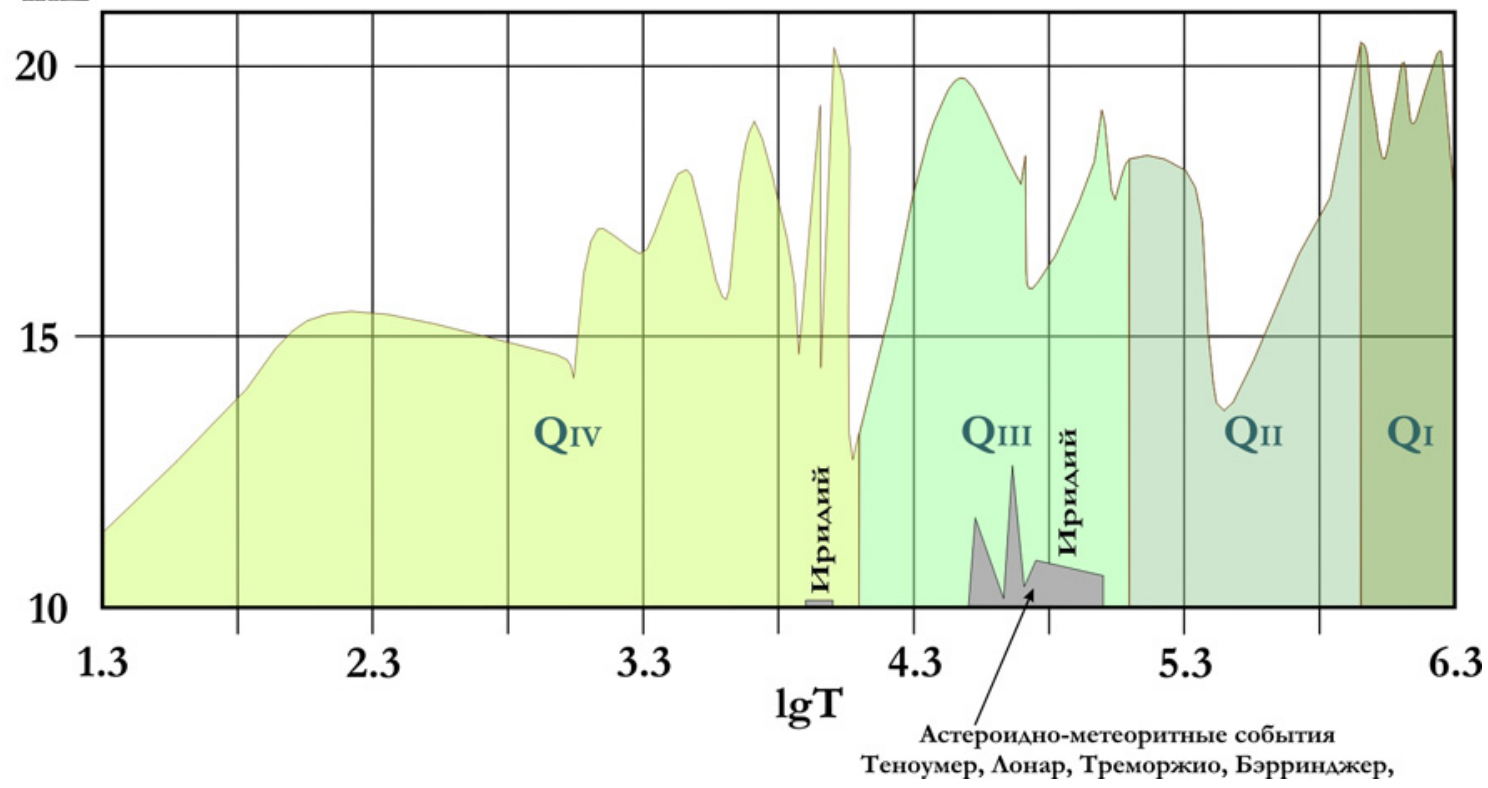

Рис. 8. Вариации выделившейся энергии при космических бомбардировках в антропогене и иридиевые аномалии.

Fig. 8. Variations in the released energy cosmic bombardments in the Quaternary and the iridium anomaly.

падения астероидов и ядер комет (рис. 8). Исходные данные для этого рисунка были заимствованы их каталога [Задонина и др., 2007]. В течение прошедших 2 млн лет Земля подвергалась космическим бомбардировкам мощностью $\mathrm{E}=10^{18}-10^{21}$ Дж 12 тыс. лет назад, 30 тыс. лет назад, 100 тыс. лет назад и трижды в раннем плейстоцене. Более детально мы рассмотрим природно-климатические изменения в позднем плейстоцене и голоцене, в периоде, события которого достаточно надежно датированы.

\section{1. МОДЕЛИРОВАНИЕ ПЕРИОДИЗАЦИИ ПРИРОДНО- КЛИМАТИЧЕСКИХ ИЗМЕНЕНИЙ}

Одним из аспектов исследований лаборатории кайнозоя ИЗК СО РАН является изучение природноклиматических изменений в историческом и доисторическом прошлом. Эти работы проводятся в целях прогноза предстоящих изменений и обеспечения устойчивого развития социума. В основу этого направления положены представления о солнечно-земных связях. В последние годы многие исследователи опираются на представления о роли орбитальных параметров Земли в формировании тех или иных природно-климатических обстановок - циклы М. Миланковича [1939]. Однако современные представления о причинах глобальных изменений все больше склоняются к существенной роли Солнца в преобразовании климата планеты. Остановимся на этом вопросе, используя сведения о развитии процессов на основе радиоуглеродного датирования геологических и биологических объектов. База данных для подобных построений опубликована [Радиоуглеродная хронология..., 2010, 2011]. Из-за краткости очерка мы не будем здесь обсуждать технологию статистического анализа данных, а приведем лишь модели, построенные по его результатам.

Мы уже упомянули, что на природно-климатическую ситуацию влияет изменение орбитальных параметров Земли: прецессии - когда происходит изменение наклона земной оси с периодом около 21-23 тыс. лет, меняющей сезонную амплитуду интенсивности солнечного потока на Северном и Южном полушариях Земли; нутации - определяющие вековые колебания угла наклона земной оси к плоскости эклиптики с периодом около 41 тыс. лет, и, наконец, долгопериодические колебания эксцентриситета орбиты Земли с периодом около 110 тыс. лет. Периодические потепления и похолодания, вызванные этими вариациями, определяют термином «циклы М. Миланковича», на которые часто ссылаются при оценках природно-климатических изменений в геологической истории Земли [1939]. Однако с их помощью очень трудно, а точнее просто невозможно, объяснить «тонкую климатическую структуру» геологических и геоархеологических разрезов конца позднего плейстоцена и голоцена (таблица). Можно предположить, что здесь не обходится без участия вариаций солнечной активности.

На рис. 9 приведены модельные кривые изменения по времени этих параметров, полученные путем суммирования гармоник относительно эпохи максимального потепления в позднем плейстоцене (Казанцевское время - около 125 тыс. лет назад). Из него видно, что именно наложение циклов М. Миланковича на вариа- 


\section{Климатическая периодизация позднего плейстоцена и голоцена}

Climatatic periodization of the Late Pleistocene and Holocene

\begin{tabular}{llll}
\hline${ }^{14}$ С-время & Сибирь & Аравия & ${ }^{14}$ С-время \\
\hline 2.5 тыс. -0 лет назад & Субатлантик & Современная аридизация & 3 тыс. -0 лет назад \\
$4.5-2.5$ тыс. лет назад & Суббореал & Ослабление аридизации & $3-4$ тыс. лет назад. \\
$8.0-4.5$ тыс. лет назад & Атлантик - тепло, встречаются зерна винограда & Начало современной аридизации & 6 тыс. лет назад \\
$9.5-8.0$ тыс. лет назад & Бореал & Трансгрессия Данкирка & $4-7$ тыс. лет назад \\
$11.0-9.5$ тыс. лет назад & Аллеред & Аридная фаза ? & $10-7$ тыс. лет назад \\
& Предбореал & Гумидная фаза & $12-10$ тыс. лет назад \\
\hline
\end{tabular}

ГОЛОЦЕН

\section{ПОЗДНИЙ ПЛЕЙСТОЦЕН $\downarrow$}

14-10 тыс. лет назад

\section{Поздний Сартан}

12.8 тыс.-11.5 тыс. лет назад - эпоха гидроката-

строф, «остановка»

Гольфстрима - тепло в Сибири и холодно в Жестокая аридизация Европе

16.0-14.5 тыс. лет назад Средний Сартан-2

18-16 тыс. лет назад

21-18 тыс. лет назад

24-21 тыс. лет назад

30-24 тыс. лет назад

33-30 тыс. лет назад

43-33 тыс. лет назад

45-43 тыс. лет назад

50-45 тыс. лет назад

110-50 тыс. лет назад

до 110 тыс. лет назад

Каргинское время - раннее похолодание

Каргинское время - раннее потепление

Ермаковское оледенение

Казанцевское межледниковье

\section{Средний Сартан-1}

Ранний Сартан-2 - холодно и сухо

Ранний Сартан-1 - холодно и влажно

Семиаридная фаза (саванновая)

36-17 тыс. лет назад

Каргинское время - Липовско-Новоселовское потепление

Каргинское время - Коношельское похолодание

Малохетский оптимум

Аридная фаза

Древнее 36 тыс. лет назад

SA, CM

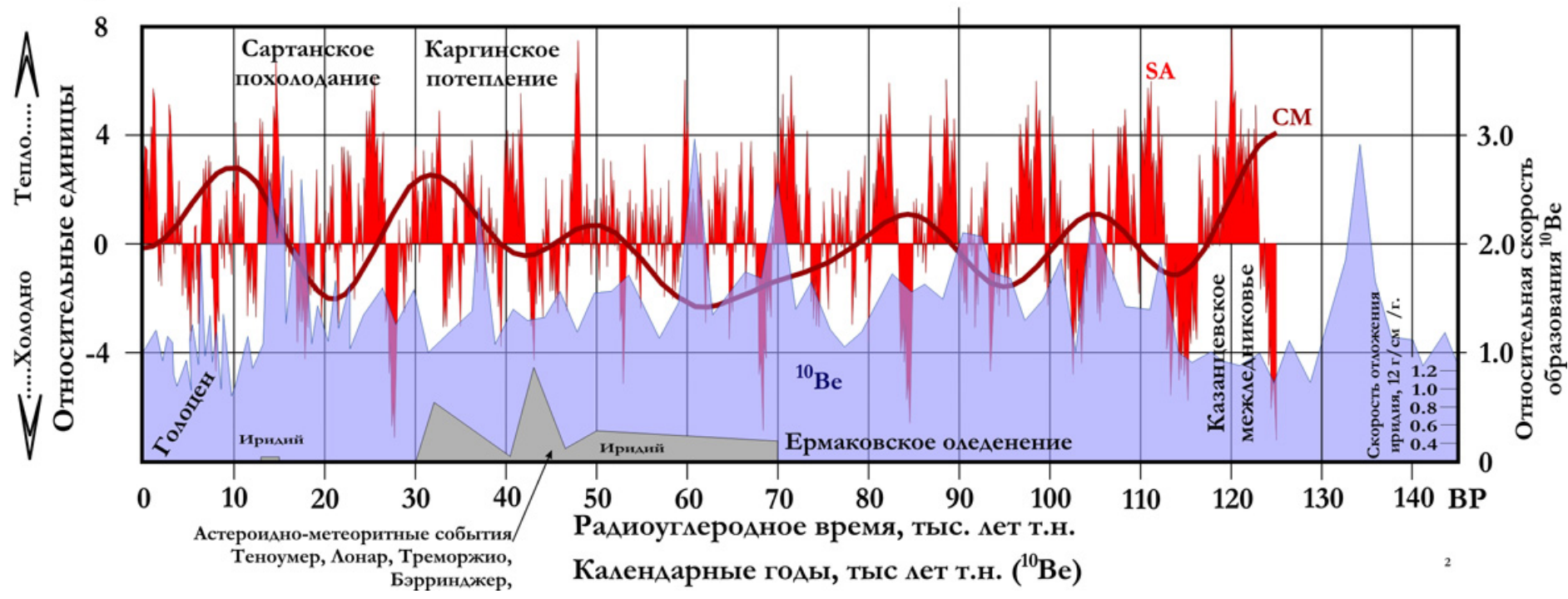

Рис. 9. Модельные кривые вариаций солнечной активности SA, орбитальных параметров Земли СM на фоне вариаций относительных скоростей образования ${ }^{10}$ Ве и отложения Ir за 125-150 тыс. лет назад.

Fig. 9. Model curves showing variations of solar activity (SA) and orbital parameters of the Earth (CM) against variations of relative velocities of ${ }^{10} \mathrm{Be}$ formation and Ir deposition for $125-150$ thousand years. 


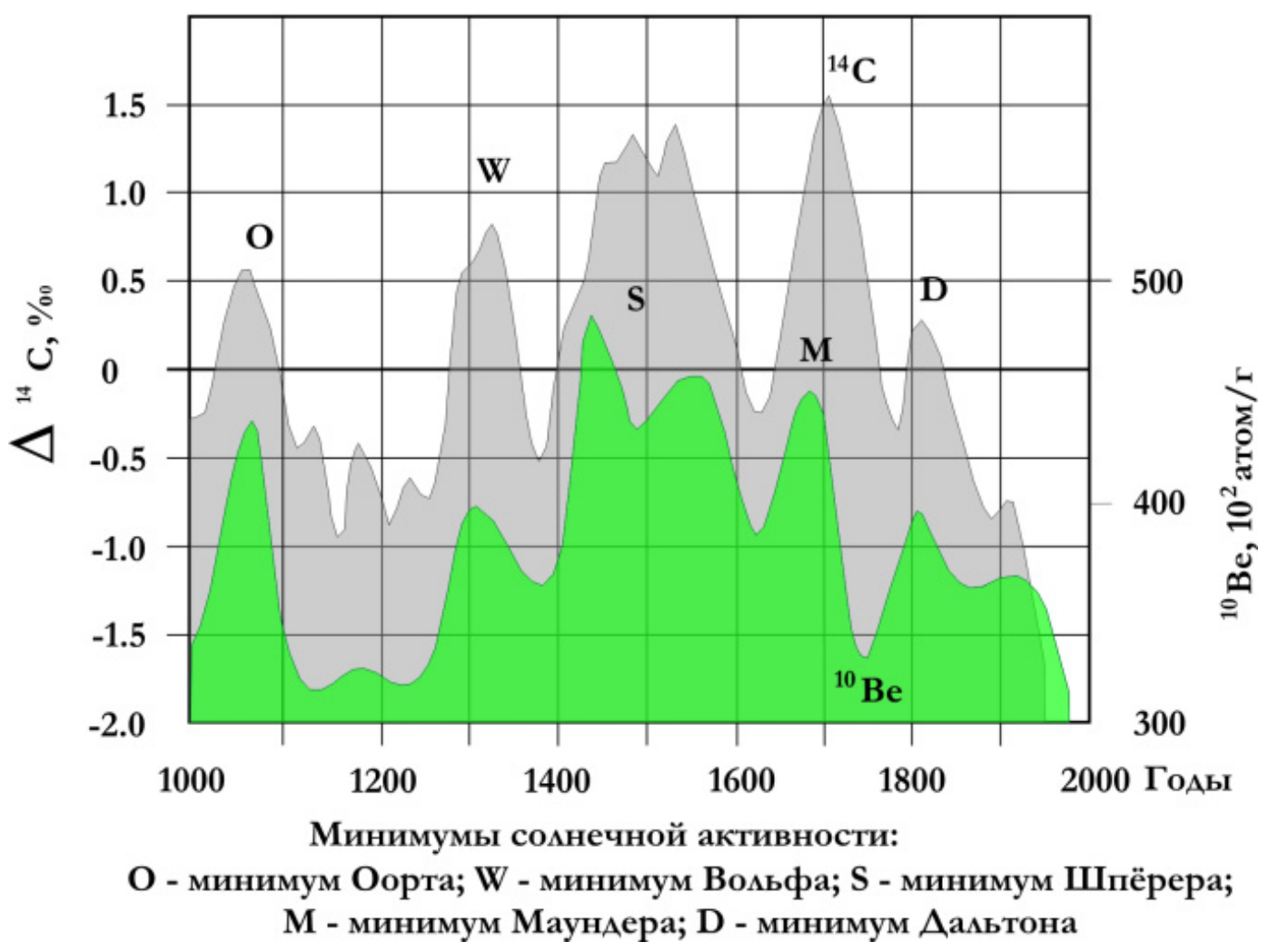

Рис. 10. Вариации концентрации ${ }^{14} \mathrm{C}$ и ${ }^{10}$ Ве в связи с изменениями долговременной солнечной активности.

Fig. 10. Variations of ${ }^{14} \mathrm{C}$ and ${ }^{10} \mathrm{Be}$ concentrations due to changes of the long-term solar activity.

ции солнечной активности обеспечивает те климатические ритмы, которые в настоящее время выделяются стратиграфами в исследуемом интервале времени. Явным показателем вариаций солнечной активности являются вариации концентраций космогенных изотопов ${ }^{14} \mathrm{C}$ и ${ }^{10}$ Ве. Их концентрации находятся в противофазе к максимумам солнечной активности и потому могут служить источником сведений о характере природноклиматических изменений на Земле (рис. 10).

Очевидно, что нельзя считать модельную кривую SA на рис. 9 совершенно достоверной, так как не удалось выявить более длительные гармоники, которые характеризовали хотя бы половину длины имеющегося ряда данных. Но это объективность, с которой приходится считаться. Дело в том, что ${ }^{14} \mathrm{C}$-хронология после примерно 30 тыс. лет назад содержит разрывы, которые, скорее, внесут различного рода искажения, чем уточнят ситуацию. Интерпретация рис. 9, с одной стороны, позволяет выявить известные главные климатические таксоны позднего плейстоцена и голоцена, а с другой - показать, что они (эти таксоны) внутренне неоднородны в результате изменения солнечной активности, ответственной за инсоляцию земной поверхности.

Несомненный интерес, в плане интерпретации рис. 11, представляют кривые, характеризующие вариации количества пыли, выпавшей на поверхность ледниковых щитов Гренландии и Антарктиды, и отклонения от средней температуры, вычисленные по данным об изменении концентрации дейтерия $\Delta \mathrm{D}$. Интересным фактом является повышение содержания пылеватых частиц в керне льда со станции «Dуe-3» в Гренландии (рис. 11) [Лавиолетm, 2008], образующих продолжительные по времени аномалии в интервале времени 70-60 и 37-15 тыс. лет назад. Аналогичные аномалии обнаруживаются в ледовом керне под ст. «Восток» в Антарктиде (рис. 12) [Борисова, 2007]. Концентрация пыли во льду не совпадает по времени ни с какими существенными космическими атаками и иридиевыми аномалиями, обычно сопровождающими их. Это может свидетельствовать в пользу повышения концентрации пыли в связи с усилением турбулентности атмосферы на фоне похолодания, мощными засухами в Африке 70-60 тыс. лет назад и аридизацией климата в Сартанскую эпоху. Синхронность же проявления аномалий говорит о том, что эти явления носили явно глобальный характер.

Поскольку изменения орбитальных параметров Земли являются периодическими, то регулярно возникают достаточно продолжительные эпохи, когда они оказывают кумулятивное влияние на климатические изменения. На рис. 13 показаны модельные вариации 


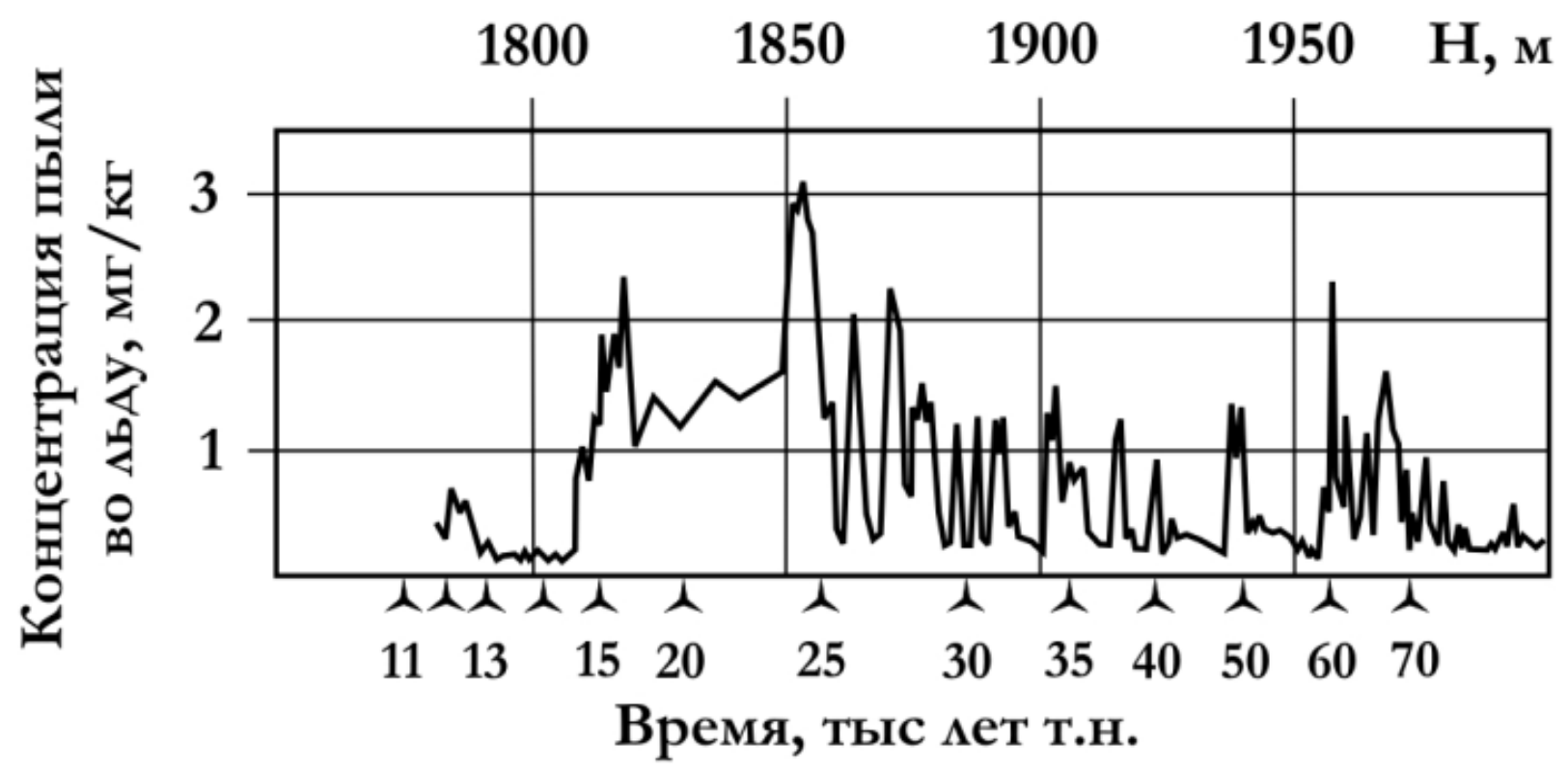

Рис. 11. Вариации концентрации пыли в ледовом керне со станции «Dуе-3» в Гренландии [Лавиолетm, 2008].

Fig. 11. Variations of dust concentrations in the ice core samples from Dye-s Station located in Greenland [Лавиолетm, 2008].

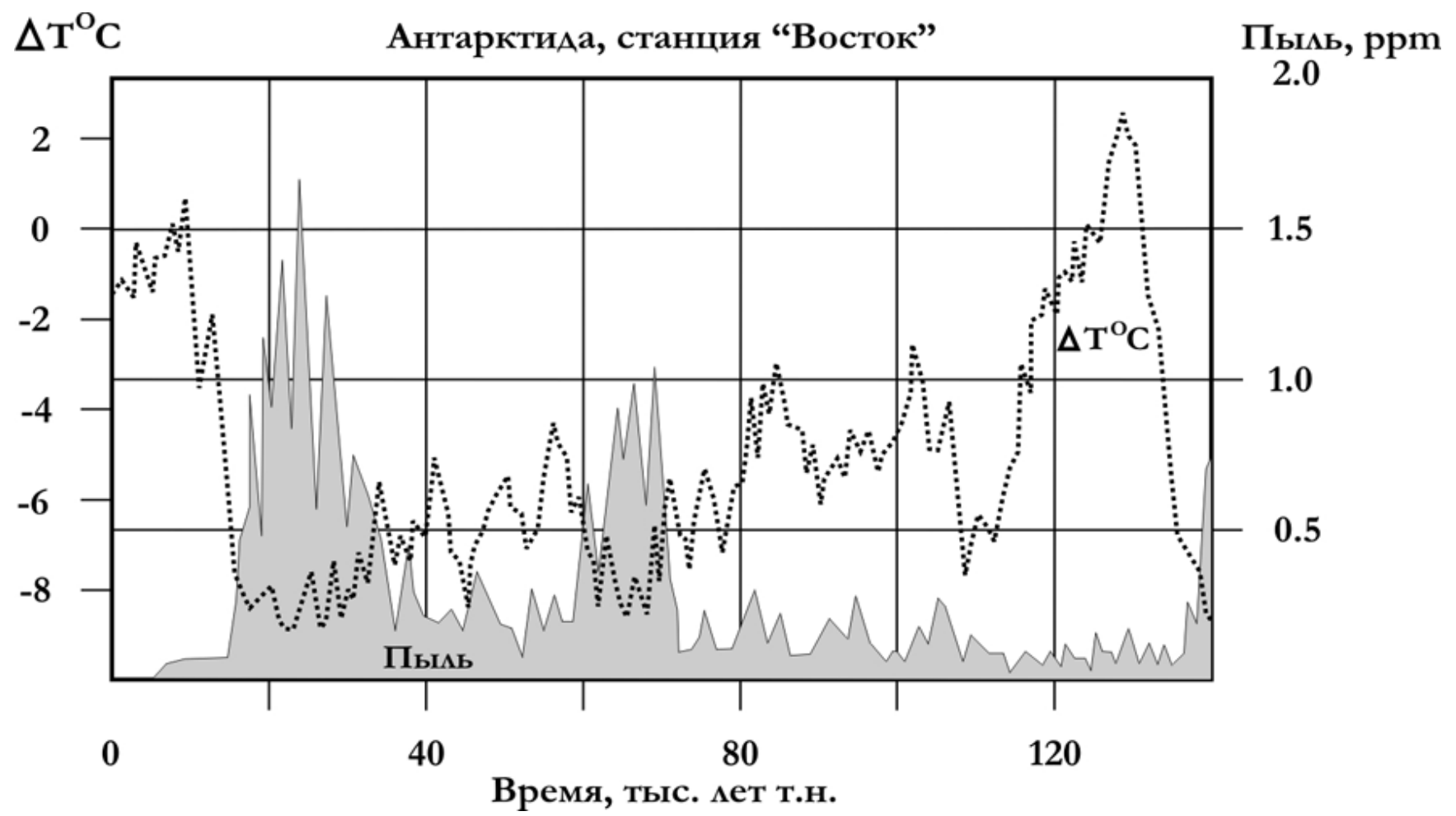

Рис. 12. Вариации приращения температуры воздуха $\Delta T^{\circ} \mathrm{C}$ и концентрации пыли в ледовом керне со станции «Восток» в Антарктиде [Борисова, 2007].

Fig. 12. Variations of air temperature increase, $\Delta \mathrm{T}\left({ }^{\circ} \mathrm{C}\right)$ and dust concentrations in the ice core samples from Vostok Station in Antarctica [Борисова, 2007]. 


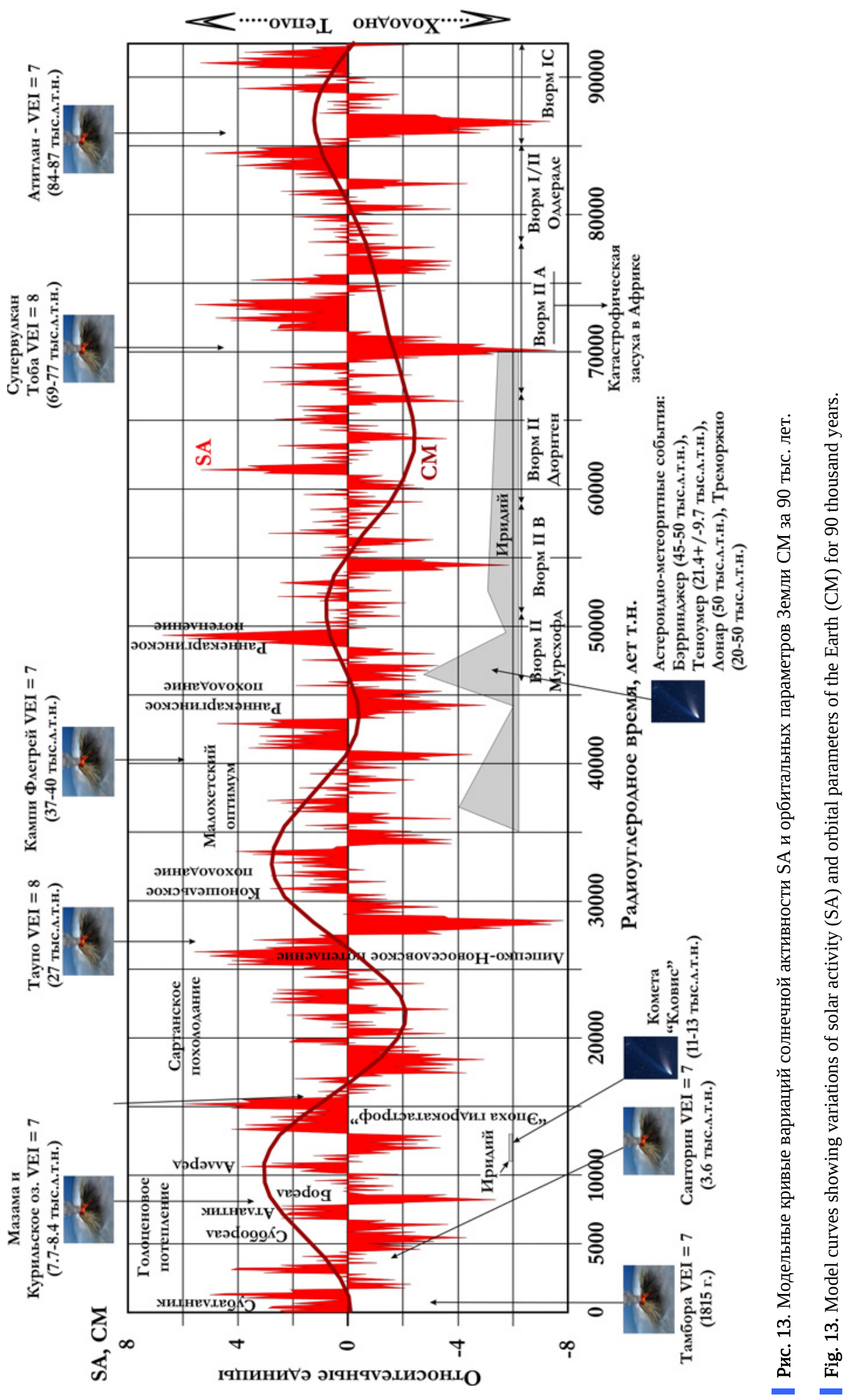




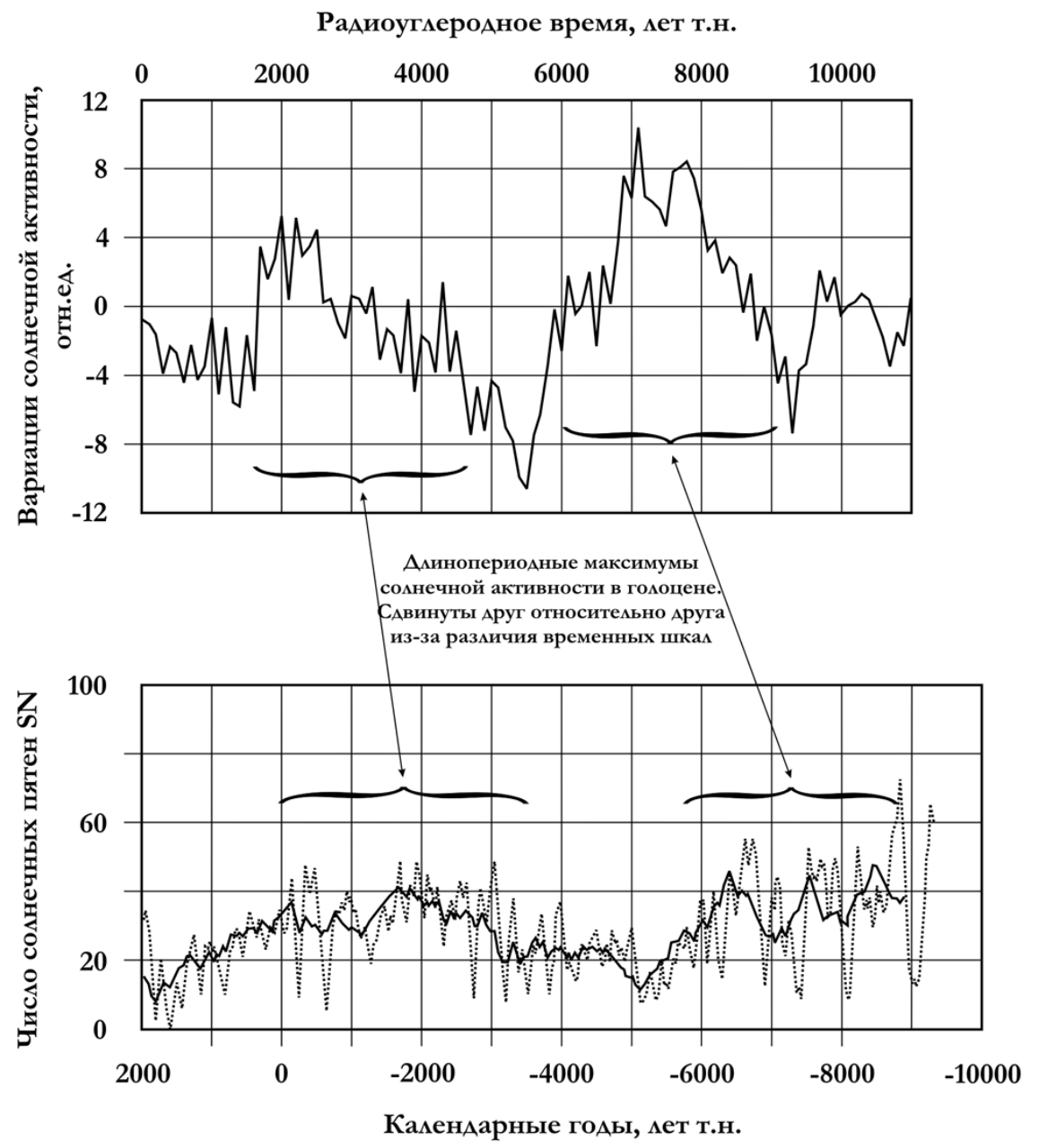

Рис. 14. Сопоставление реконструированных по величине концентрации ${ }^{14} \mathrm{C}$ в кольцах деревьев значений чисел солнечных пятен SN [Solanki et al., 2004] (внизу) и модельной кривой (вверху), отражающих вариации солнечной активности для последних 11 тыс. лет.

Данные на кривой [Solanki et al., 2004] сглажены 100-летним (пунктир) и 500-летним окном.

Fig. 14. Comparison of sunspot numbers (SN) reconstructed from ${ }^{14} \mathrm{C}$ concentrations in annual wood growth rings, according to [Solanki et al., 2004] (bottom), and the model curve (top), which show variation of solar activity for the past 11 thousand years.

The data on the curve from [Solanki et al., 2004] are fit in the 100-year (dotted line) and 500-year windows.

солнечной активности SA (красное поле) и орбитальных параметров Земли СМ (сплошная коричневая линия). Сюда же помещены сведения об иридиевых аномалиях (см. рис. 9), мощнейших извержениях вулканов с эксплозивным индексом VEI $\geq 7-8$ и традиционных природно-климатических таксонах.

При построении модельных кривых (рис. 13) временной ряд был сокращен до 90 тыс. лет назад, поскольку в интервале 67-78 тыс. лет назад в природноклиматических изменениях Северного полушария наступил кризис - катастрофическая засуха в Африке, которая привела к грандиозному вымиранию популяции Homo sapiens и миграции ее остатков в Евразию. Считают, что около 80 тыс. лет назад кроманьонцы проникли на Аравийский п-ов, а оттуда в Индию и на Восточно-Европейскую равнину. Последовательные извержения вулканов Атитлан и Тоба привели к затяжному похолоданию за счет выбросов в атмосферу продуктов вулканических извержений, которые существенно снизили инсоляцию земной поверхности и способствовали развитию длительных похолоданий при благоприятных для этого обстоятельствах - изменении орбитальных параметров Земли и снижении солнечной активности на длительные сроки, превышающие по продолжительности известные минимумы Оорта, Вольфа, Шперера, Маундера и т.д. Немаловажную роль в этом сыграли и космические бомбардировки, способствовавшие замутнению атмосферы пылью от взрывов и дымом возникавших при этом пожаров.

На рис. 14 приведен график, заимствованный из работы [Solanki et al., 2004], реконструирующий вариа- 
ции числа солнечных пятен по концентрации ${ }^{14} \mathrm{C}$ в кольцах деревьев за последние 11 тыс. лет.

Визуальное сравнение кривых на рис. 13, различных по своей структуре и способам построения, показывает их сходство в общих чертах. Известно, что кривая [Solanki et al., 2004] построена с 10-летним разрешением. Возможности данного исследования были ограничены лишь 100-летним разрешением, но главное состоит в том, что сравнение кривых говорит о приемлемости предложенного подхода к анализу данных радиоуглеродного датирования для оценки длительных солнечных ритмов и удовлетворительном согласии этих ритмов с климатической периодичностью в позднем плейстоцене и голоцене.

Таким образом, анализ радиоуглеродных датировок геологических и биологических объектов позволяет реконструировать с должной детальностью периодичность смены природно-климатических обстановок в позднем плейстоцене - голоцене, но нуждается в детализации. Такая детализация возможна лишь при тщательном анализе исторических хронологий тех или иных природных явлений с целью среднесрочного и долгосрочного прогноза природных изменений в ближайшие десятилетия, что и выполняется в настоящее время [Гелиогеодинамика..., 2012, 2013].

\section{2. ФАУНА КРУПНЫХ МЛЕКОПИТАЮЩИХ В БАЙКАЛЬСКОЙ СИБИРИ*}

Важный аспект в исследовании природно-климатических изменений - изучение и временная привязка ископаемой голоценовой фауны и характерных особенностей среды ее обитания, что приводило к возникновению природных кризисов и вымиранию главным образом мегафауны позднего плейстоцена. Это региональный аспект, без изучения которого невозможны глобальные реконструкции природно-климатических обстановок.

На территории Юго-Западного Прибайкалья были обнаружены ископаемые материалы из опорных разрезов позднего неоплейстоцена (последние 50 тыс. лет). Весь объем собранных коллекций позволил отобрать образцы для радиоуглеродного датирования как самих разрезов, так и конкретных видов плейстоценовой фауны. В опорных разрезах отложений впадин Тункинской рифтовой долины были выделены фаунистические ассоциации [Щетников и др., 2013] для разных этапов развития природной обстановки. Наиболее богатыми по видовому составу являются фауны второй половины каргинского времени - зактуйская и зангисанская. В абсолютном летоисчислении они датируются в пределах 33-36 тыс. лет назад и включают мамонта шерстистого, носорога шерстистого, два вида лошадей, кулана, благородного оленя, косулю, дзерена, антилопу винторогую и крокуту пещерную. Значитель-

\footnotetext{
* Раздел подготовлен А.М. Клементьевым и А.В. Сизовым.
}

ные перспективы для изучения фауны этого отрезка позднего неоплейстоцена обещает комплексное исследование геоархеологического объекта Туяна. Уже сейчас здесь выявлено присутствие остатков двенадцати видов крупных млекопитающих, составляющих единый комплекс.

Уникальным объектом является разрез Славин Яр, где фаунистические остатки обнаружены на разных стратиграфических уровнях. Наиболее богато здесь представлен восьмиметровый уровень (мамонт шерстистый, кулан, носорог шерстистый, благородный

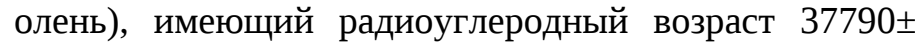
\pm 310 лет назад. На глубине 11 м залегает следующий

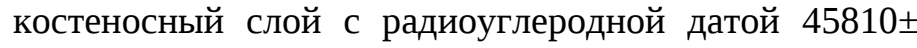
\pm 4070 лет назад, здесь были найдены кости мамонта и косули. Интересна находка на глубине 18-19 м остатков Ursus arctos и Equus sp. По стратиграфическому положению в разрезе этот костеносный слой вероятнее всего был сформирован в самом начале каргинского потепления (около 57 тыс. лет назад). Славиноярская фаунистическая ассоциация датирована в широких пределах первой половиной каргинского времени. Таким образом, мамонтовый (или позднепалеолитический) комплекс Тункинского рифта расчленяется на несколько разновозрастных фаун. Каргинские фауны имеют своеобразные особенности, сближающие регион с Западным Забайкальем: обилие шерстистого носорога, присутствие дзерена, кулана и грацильной лошади. Имеются и локальные черты - это значительное количество благородного оленя и косули. Экологический анализ фауны позволяет говорить о существенных отличиях тункинских фаунистических ассоциаций от ассоциаций сартанского времени. Известные данные о возрасте и фауне стоянки Мальта позволяют охарактеризовать ее как преимущественно тундровую [Ермолова, 1978]. Фауны каргинского термохрона Тункинской долины являются в основе степными. Материалы по фауне сартанского криохрона Тункинского рифта также были датированы радиоуглеродным методом. Датировки свидетельствуют об обитании шерстистого носорога и пещерного льва позже максимума сартанского криохрона. И хотя палеонтологические остатки сартанского возраста в Тункинской впадине разрозненны и малочисленны, состав фауны (пещерная кошка, шерстистый носорог, лошадь, первобытный бизон, северный олень) не противоречит широким возможностям корреляций на юге Восточной Сибири, тем более что Олхинское плато не могло являться значительной преградой для крупных млекопитающих.

Продолжается работа по изучению палеонтологических материалов, получаемых археологическими экспедициями на территории Приангарья и Забайкалья. Эти материалы укладываются в широкий хронологический диапазон - от верхнего эоплейстоцена (Засухино) до позднего голоцена (средневековые объекты). Основной массив данных приходится также на финал неоплейстоценовой эпохи. По результатам изу- 
чения фаунистических ассоциаций бассейна реки Уда была предложена реконструкция ландшафтных обстановок этого района Забайкалья [Клементьев, 2011]. В тесном сотрудничестве с иркутскими археологами ведется работа по интерпретации палеофаунистических материалов Приангарья. Были изучены многолетние сборы костных остатков каргинского времени, что позволило реконструировать природные условия на территории Иркутского амфитеатра на рубеже XXX тысячелетия [Клементьев, 2013]. Значительно пополнились сведения о фауне сартанского криохрона благодаря изучению материалов объектов Мост - Левый Берег, Советская-1, Щапово-2. Объемные фаунистические коллекции многослойных объектов голоцена (Усть-Хайта, Бугульдейка-2, Лиственничный, УстьЁдарма-2, Усть-Кеуль-1) позволяют выйти на подробные характеристики развития фауны в течение последних 12 тысяч лет. В частности, установлено присутствие в фауне раннего голоцена первобытного бизона и ископаемой лошади - как в Южном, так и в Северном Приангарье. Точные сроки их вымирания неизвестны, но костные останки крупного бизона определены в неолитических комплексах Братского водохранилища. Присутствие первобытного быка датировано на берегах Южного Байкала поздним неолитом. Самые поздние, средневековые, комплексы фаунистических остатков, в комплексе с археологическими данными, позволяют проводить хозяйственные реконструкции жизни населения. В частности, особенности видового состава домашних млекопитающих и промысловых видов позволили установить скотоводческую основу хозяйства населения рубежа I-II тыс. н.э. [Клементьев, Николаев, 2013].

\section{4. ЗАКЛЮЧЕНИЕ}

Анализ пространственно-временного распределения высоко- и умереннокаливых базальтовых извержений в Центральной Монголии и морских записей изотопов $\mathrm{Sr}$ выявил соответствие начала новейшего геодинамического этапа этой территории точке отсчета его глобального выражения. Такое соответствие свидетельствует о тесной связи магматических событий Центральной Монголии с глобальными процессами конвергенции и позволяет рассматривать их в качестве представительных для новейшей геодинамической эволюции последних 90 млн лет, в ходе которой определена важнейшая роль рубежей 66, 40-37, 32 и 17-15 млн лет назад. Происходившие глобальные изменения, за исключением рубежа 32 млн лет назад, запечатлены в морских записях изотопов $\mathrm{Sr}$.

Восстановлена природно-климатическая периодизация позднего плейстоцена - голоцена на основе анализа радиоуглеродных датировок геологических и палеобиологических объектов в Северном полушарии. Построена модельная кривая, отражающая изменения природной среды и климата с учетом вариаций солнечной активности, циклов М. Миланковича, проявления мощных вулканических извержений, астероиднометеоритных атак и изменения видового состава региональной фауны на заданном временном интервале.

\section{5. ЛИТЕРАTУРA / REFERENCES}

Борисова О.К. Изменения растительности и климата умеренных широт Южного полушария за последние 130000 лет (в сопоставлении с Северным полушарием): Автореф. дис. ... докт. биол. наук. М., 2007. 48 с.

Гелиогеодинамика: Природные аспекты глобальных солнечных минимумов. В 3 т. Т. 1, кн. 1 / К.Г. Леви, Н.В. Задонина, С.А. Язев, В.И. Воронин, М.М. Наурзбаев, Р.М. Хантемиров. Иркутск: Изд-во ИГУ, 2012. 511 с.

Гелиогеодинамика: Природные аспекты глобальных солнечных минимумов. В 3 т. Т. 1, кн. 2 / К.Г. Леви, Н.В. Задонина. Иркутск: Изд-во ИГУ, 2012. 667 с.

Гелиогеодинамика: Природные аспекты глобальных солнечных минимумов. В 3 т. Т. 1, кн. 3 / К.Г. Леви, Н.В. Задонина. Иркутск: Изд-во ИГУ, 2013. 727 с.

Гелиогеодинамика: Природные аспекты глобальных солнечных минимумов. В 3 т. Т. 1, кн. 4 / К.Г. Леви, Н.В. Задонина. Иркутск: Изд-во ИГУ, 2013. 607 с.

Геология и сейсмичность зоны БАМ. Неотектоника / С.И. Шерман, К.Г. Леви, В.В. Ружич, В.А. Саньков, Ю.И. Днепровский, С.В. Рассказов. Новосибирск: Наука, 1984. - 207 с.

Ермолова Н.М. Териофауна долины Ангары в позднем антропогене. Новосибирск: Наука, 1978. 222 с.

Задонина Н.В., Леви К.Г., Язев С.А. Космические опасности геологического и исторического прошлого Земли. Анализ временных рядов. Иркутск: ИЗК СО РАН, 2007. 77 с.

Клементьев А.М. Ландшафты бассейна реки Уды (Забайкалье) в позднем неоплейстоцене (по фауне крупных млекопитающих): Автореф. ... канд. геогр. наук. Иркутск, 2011. 21 с.

Клементьев А.М. Фауны позднекаргинского времени Иркутского амфитеатра // Известия Иркутского государственного университета. Серия «Геоархеология. Этнология. Антропология». 2013. № 1 (2). С. 30-43.

Клементьев А.М., Николаев В.С. Археозоологическая характеристика поселения Тоток (Южное Приангарье, Сибирь) // Зоологический журнал. 2013. Т. 92. № 9. С. 1088-1097. 
Корина Н.А. Хангайское нагорье // Геоморфология Монгольской народной республики. Труды Совместной Советско-Монгольской научно-исследовательской экспедиции. Вып. 28. М.: Наука, 1982. С. 87-108.

Лавиолетт П. Лед и Огонь. История глобальных катастроф. М.: Вече, 2008. 508 с.

Леви К.Г. Неотектонические движения в сейсмоактивных зонах литосферы. Новосибирск: Наука, 1991. 166 с.

Леви К.Г. Карта неотектоники северо-восточного сектора Азии. Иркутск: ГП «475 Военно-топографическая фабрика», 2008.

Леви К.Г., Задонина Н.В., Язев С.А., Воронин В.И. Современная геодинамика и гелиогеодинамика. Учебное пособие. Иркутск: Изд-во Иркут. гос. ун-та, 2012. 539 с.

Логачев Н.А., Шерман С.И., Леви К.Г. О принципах и методике составления карты новейшей тектоники Сибири // Методические рекомендации к Атласу тектонических карт и опорных профилей Сибири. Новосибирск, 1981. С. 12-20.

Миланкович М. Математическая климатология и астрономическая теория колебаний климата. М.-Л.: ГОНТИ-НКТП, 1939. 247 c.

Николаев Н.И. Новейшая тектоника СССР (Труды комиссии по изучению четвертичного периода). М.-Л.: Изд-во АН СССР, 1949. 342 с.

Радиоуглеродная хронология природных и социальных феноменов Северного полушария. В 3 т. Т. 1 / К.Г. Леви, Н.В. Задонина, С.А. Язев. Иркутск: Изд-во Иркут. гос. ун-та, 2010. 715 с.

Радиоуглеродная хронология природных и социальных феноменов Северного полушария. В 3 т. Т. 2 / К.Г. Леви, Н.В. Задонина, С.А. Язев. Иркутск: Изд-во Иркут. гос. ун-та, 2011. 527 с.

Радиоуглеродная хронология природных и социальных феноменов Северного полушария. В 3 т. Т. 3 / К.Г. Леви., Н.В. Задонина, С.А. Язев. Иркутск: Изд-во Иркут. гос. ун-та, 2011. 847 с.

Рассказов С.В. Ритмы позднекайнозойского вулканизма юго-восточной части Евразиатской плиты // Атлас временных вариаций природных, антропогенных и социальных процессов. Т. 3. Природные и социальные сферы как части окружающей среды и как объекты воздействий. М.: Янус-К, 2002. С. 184-189.

Рассказов С.В., Логачев Н.А., Брандт И.С., Брандт С.Б., Иванов А.В. Геохронология и геодинамика позднего кайнозоя (Южная Сибирь - Южная и Восточная Азия). Новосибирск: ВО Наука. Сибирское отделение, 2000. 288 с.

Рассказов С.В., Чувашова И.С. Кайнозойские динамические экстремумы в эпизодах извержений коровых выплавок в орогенных и рифтовых структурах Азии // Геодинамическая эволюция литосферы Центрально-Азиатского подвижного пояса (от океана к континенту): Материалы совещания. Вып. 10. Иркутск: ИЗК СО РАН, 2012. Т. 2. С. $51-54$.

Рассказов С.В., Чувашова И.С. Глобальное и региональное выражение новейшего геодинамического этапа // Бюллетень МОИП. Отд. геологический. 2013а. Т. 88. Вып. 4. С. 21-35.

Рассказов С.В., Чувашова И.С. Новейшая мантийная геодинамика Центральной Азии. Иркутск: Изд-во ИГУ, $2013 б$. 308 c.

Свидетельство о государственной регистрации базы данных № 2013620655 Кайнозойские вулканические породы Азии. База данных по химическому и изотопному составу / С.В. Рассказов, Т.А. Ясныгина, И.С. Чувашова, М.Е Маркова - Заявка № 20113620317. Зарегистрировано в Реестре баз данных 27 мая 2013 г.

Хаин В.Е. Основные проблемы современной геологии. М.: Научный мир, 2003. 348 с.

Чувашова И.С., Рассказов С.В., Брандт С.Б. Цикличные вариации калия в позднекайнозойских лавах Центральной Монголии // Известия ИГУ. Серия наук о Земле. 2010. Т. 3. № 1. С. 159-176.

Щетников А.А., Клементьев А.М., Сизов А.В., Филинов И.А., Семеней Е.Ю. Новые данные о возрасте неоплейстоценовых отложений Тункинской рифтовой долины (Юго-Западное Прибайкалье) по результатам ${ }^{14} \mathrm{C}$ датирования фауны крупных млекопитающих // Доклады АН. 2013. Т. 449. № 2. С. 199-204.

Ярмолюк В.В., Иванов В.Г., Коваленко В.И., Самойлов В.С. Динамика формирования и магматизм позднемезозойскокайнозойской Южно-Хангайской горячей точки мантии (Монголия) // Геотектоника. 1994. № 5. С. $28-45$.

Ярмолюк В.В., Коваленко В.И., Иванов В.Г. Внутриплитная позднемезозойская - кайнозойская вулканическая провинция Центральной Восточной Азии - проекция горячего поля мантии // Геотектоника. 1995. № 5. С. 41-67.

Ярмолюк В.В., Кудряшова Е.А., Козловский А.М., Саватенков В.М. Позднемеловой - раннекайнозойский след ЮжноХангайской горячей точки мантии // Вулканология и сейсмология. 2007. № 1. С. 3-31.

Arndt N., Lesher C.M., Barnes S.J. Komatiite. Cambridge University Press, 2008. 458 p.

Enkhtuvshin H. A petrological study on the Late Mesozoic and Cenozoic volcanic rocks of the Mongolian Plateau: Master thesis. Shimane University, 1995. 119 p.

Glass B.P. Upper Eocene impact ejecta/spherule layers in marine sediments // Chemie der Erde - Geochemistry. 2002. V. 62. № 3. P. 173-196. http://dx.doi.org/10.1078/0009-2819-00017.

Koeberl C., Poag C.W., Reimold W.U., Brandt D. Impact origin of Chesapeake Bay structure and the source of North Ameri- 
can tektites // Science. 1996. V. 271. P. 1263-1266. http://dx.doi.org/10.1126/science.271.5253.1263.

McArthur J.M., Howarth R.J., Bailey T.R. Strontium isotope stratigraphy: LOWESS version 3: best fit to the marine Srisotope curve for 0-509 Ma and accompanying look-up table for deriving numerical age // Journal of Geology. 2001. V. 109. P. 155-170. http://dx.doi.org/10.1086/319243.

Rasskazov S.V., Brandt S.B., Brandt I.S. Radiogenic isotopes in geologic processes. Springer, Dordrecht, Heidelberg, London, New York, 2010. 306 p.

Rasskazov S., Taniguchi H. Magmatic response to the Late Phanerozoic plate subduction beneath East Asia. CNEAS Monograph Series No. 21. Tohoku University, Japan, 2006. 156 p.

Sanford W. Heat flow and brine generation following the Chesapeake Bay bolide impact // Journal of Geochemical Exploration. 2003. V. 78-79. P. 243-247.

Solanki S.K., Usoskin I.G., Kromer B., Schüssler M., Beer J. Unusually active Sun during recent decades compared to the previous 11,000 years // Nature. 2004. V. 431. № 7012. P. 1084-1087. http://dx.doi.org/10.1038/nature02995.

Ward P.D. Out of thin air: dinosaurs, birds, and Earth's ancient atmosphere. The National Academic Press, 2006. 296 p.

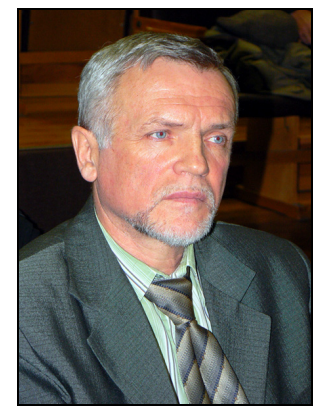

Рассказов Сергей Васильевич, докт. геол.-мин. наук, профессор, зав. лабораторией

Институт земной коры СО РАН

664033, Иркутск, ул. Лермонтова, 128, Россия

Тел. (3952)511659; $\bowtie$ e-mail: rassk@crust.irk.ru

Иркутский государственный университет, геологический факультет, зав. кафедрой динамической геологии

Rasskazov, Sergey V., Doctor of Geology and Mineralogy, Professor, Head of Laboratory Institute of the Earth's Crust, Siberian Branch of RAS

128 Lermontov street, Irkutsk 664033, Russia

Tel. +7(3952)511659; $\bowtie$ e-mail: rassk@crust.irk.ru

Head of the Department of Dynamic Geology, Geological Faculty, Irkutsk State University

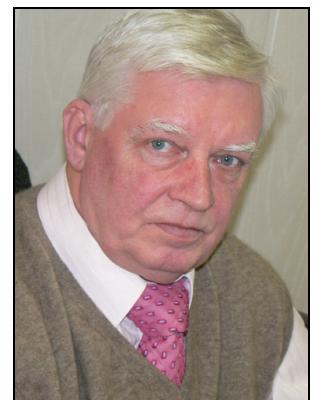

Леви Кирилл Георгиевич, докт. геол.-мин. наук, профессор, зам. директора института по науке Институт земной коры СО РАН

664033, Иркутск, ул. Лермонтова, 128, Россия

Тел. (3952)424562; e-mail: levi@crust.irk.ru

Levi, Kirill G., Doctor of Geology and Mineralogy, Professor, Deputy Director

Institute of the Earth's Crust, Siberian Branch of RAS

128 Lermontov street, Irkutsk 664033, Russia

Tel. +7(3952)424562; e-mail: levi@crust.irk.ru 